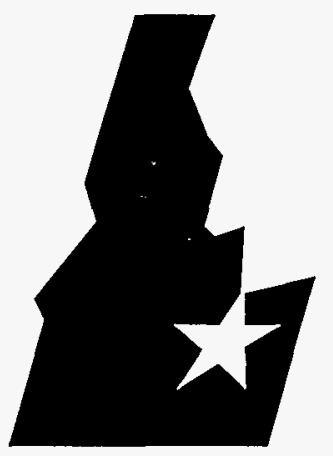

Idaho

National

Engineering

Laboratory
INEL-96/0332

-IFCEIVED September 1995 OCT 071996

OSTI

\section{Inter-Site SNF Shipment Preparation Plan}

\section{E. D. Houck \\ J. Jefimoff}

This report was prepared as an account of work sponsored by an agency of the United States Government. Neither the United States Government nor any agency thereof, nor any of their employees, makes any warranty, express or implied, or assumes any legal liability or responsibility for the accuracy, completeness, or usefulness of any information, apparatus, product, or process disclosed, or represents that its use would not infringe privately owned rights. Reference herein to any specific commercial product, process, or service by trade name, trademark, manufacturer, or otherwise does not necessarily constitute or imply its endorsement, recommendation, or favoring by the United States Government or any agency thereof. The views and opinions of authors expressed herein do not necessarily state or reflect those of the United States Government or any agency thereof.

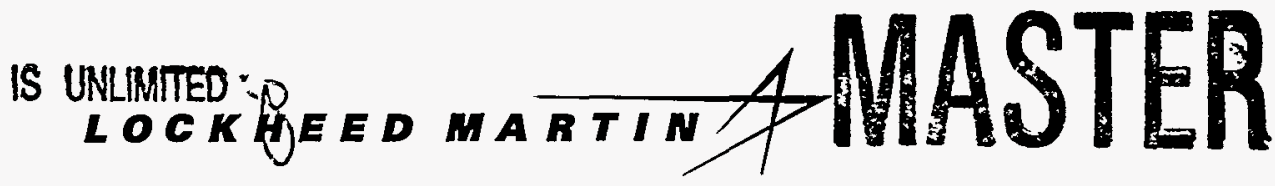


INEL-96/0332

\section{Inter-Site SNF Shipment Preparation Plan}

E. D. Houck

J. Jefimoff

Published September 1996

Idaho National Engineering Laboratory

INEL Spent Nuclear Fuel Department

Lockheed Idaho Technologies Company

Idaho Falls, Idaho 83415

Prepared for the

U.S. Department of Energy

NMSTG: EM-60

Under DOE Idaho Operations Office

Contract DE-AC07-94ID13223 


\section{DISCLAIMER}

Portions of this document may be illegible in electronic image products. Images are produced from the best available original document. 


\section{Summary}

The Inter-Site SNF Shipment Preparation Plan provides the information on the activities, times, description, schedule, and cost of a generic inter-site SNF shipment preparation and shipment campaign that can be used for the development of a specific inter-site SNF shipment campaign. It provides the basis and method for estimating site-specific activities, times, description, schedule, and costs. The schedule that is provided shows the interaction of the activities and with the provided set of blank inter-site SNF shipment preparation tables provides for the development of a specific SNF shipment case. The sum of these features provides the reader and user with a tool by which an inter-site SNF shipment campaign can be setup and successfully completed. The generic cost estimate and times were derived primarily from INEL experiences and detailed cost estimates for shipments and receipts, in particular from Russ Cottam, as well as the experiences, cost estimates and reviews from the Savannah River Site, Oak Ridge, and West Valley. Electronic versions of the tables and schedules are available by disk or E-mail to interested users. 


\section{Table of Contents}

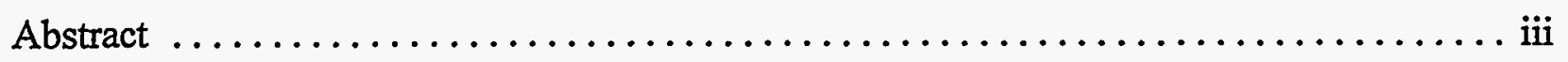

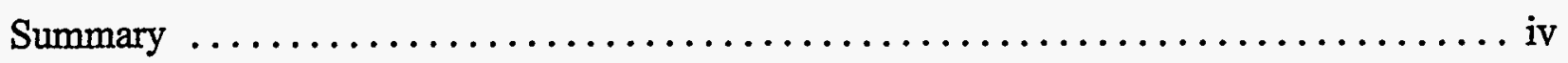

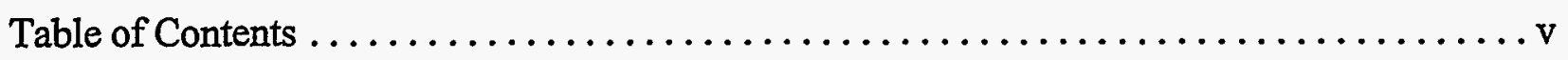

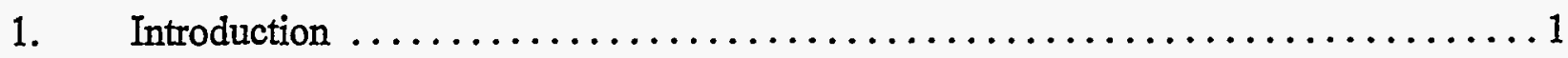

2. Inter-Site SNF Shipment Preparation Plan $\ldots \ldots \ldots \ldots \ldots \ldots \ldots \ldots \ldots \ldots \ldots \ldots \ldots \ldots \ldots$

3. Generic SNF Shipment Tables and and Descriptions $\ldots \ldots \ldots \ldots \ldots \ldots \ldots \ldots$

4. Blank Inter-Site SNF Preparation Plan Tables $\ldots \ldots \ldots \ldots \ldots \ldots \ldots \ldots \ldots \ldots \ldots \ldots \ldots$

5. Generic Inter-Site SNF Shipment Preparation Plan Schedules

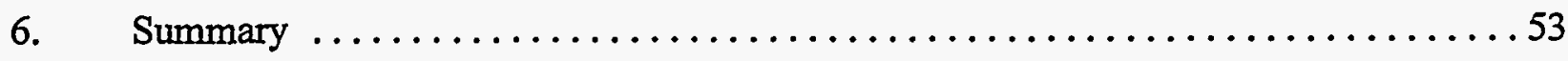




\section{Introduction}

The Inter-Site SNF Shipment Preparation Plan is based on generic numbers. The generic numbers are those reasonably expected time frames and costs for accomplishing the various tasks associated with preparing for and implementing a spent fuel shipping and receipt campaign.

The Inter-Site SNF Shipment Preparation Plan provides the information of the activities, times, description, schedule, and cost of a generic inter-site SNF shipment preparation and shipment campaign. It provides the basis and method for estimating site-specific activities, times, description, schedule, and costs. It also provides a set of blank inter-site SNF shipment preparation tables for the development of a specific SNF shipment case. The detailed schedule shows the interaction between the activities and allows for the critical path planning as well as identifying the impacts of a lengthened or shortened activity. The sum of these features provides the reader and user with a tool by which an inter-site SNF shipment campaign can be setup and successfully completed. 


\section{Inter-Site SNF Shipment Preparation Plan}

The Preparation Plan is used by reviewing the generic numbers for the activities and then filling in the set of blank tables with the appropriate modifications of the generic numbers. The generic time numbers give the typical time required to perform the task as well as the range of times that could be expected for the activity. A few cases will fall out of the given range. Likewise, the costs given are for the typical case and are given in FY-96 dollars. For a specific shipping campaign, some items maybe easier or harder than the typical case and the generic cost and time numbers can be adjusted to improve the accuracy of the cost and schedule estimate. For instance, if the cask to be leased is a standard cask with the usual requirements and modifications, then Table S04 numbers would be used as is. If the shipper's facilities are up and running, then the Table S03 numbers would be greatly reduced or even zeroed out. By making the appropriate modification as presently understood, the first set of tables for a new set of shipments would be developed. Since the relationships and the tie points stay the same, the first schedule would be easily developed from the shipment tables. As more information is gathered and the process of planning develops further, then the tables and schedules can be updated to provide an even better estimate for budgeting, planning, and performing the SNF preparations and shipments. The generic cost estimate and times were derived primarily from INEL experiences and detailed cost estimates for shipments and receipts as well as the experiences and cost estimates from the Savannah River Site, Oak Ridge, and West Valley. 


\section{Generic SNF Shipment Tables and and Descriptions}

The attached tables and schedules are generic, i.e., they cover all the activities that could be required to ship SNF. Table 1 summarizes all of the activities that could be required in SNF shipments. Tables J01 through R16 and, as applicable to the cask option selected, S5A or S5B that succeed Table 1 are the major activities and subactivities for preparation and shipment of the fuel. These tables are specifically intended to cover the generic or base SNF shipment case, the case in which all activities are included as detailed below. The tables break the activities down into three performing organizations that represent the responsibility for each table of actions: joint receiver and shipper, receiver, and shipper. Each responsible organization then has a subtable of activities for each major set of activities/tables. Tables R02 to R16 cover the receiving site activities. Tables S02 to S16, S5A and S5B cover the shipping site activities. Table J01 covers the receiver and shipper activities. The tables proceed in chronological order, i.e., the joint activities are the first to occur, J01, followed by the shipper, S02, and the receiver, R02, general preparation activities, and so on. As is shown by the schedule, Section 5, the tables and activities have several internal and intra-table ties so the activities of one table typically start and stop before and after the preceding table and following tables have finished and started, respectively.

The base case covers the leasing of a cask. Three alternates to leasing are: using an existing DOE cask, buying a cask or a dual purpose cask (DPC), and buying a multi-purpose canister (MPC) or special purpose MPC. The tables are set up to be all inclusive with four major options: using an existing DOE cask (Tables S5A\&B and item S04-01 not used), using/leasing an existing commercial cask (Tables S5A\&B not used), buying a cask (Table S5B and items S04-01, -02, 03 not used), and buying a DPC, MPC or special purpose MPC (Table S5A and items S04-01, $02,-03$ not used). These tables are all inclusive and thus cover SNF shipments from the initial steps through shipment and receipt.

The SNF Shipment Table and Schedules are for activities required from the beginning to the end of the SNF preparation and shipment. When specific cases are being modeled, items or even entire tables will be zeroed if the activities are not applicable or have already been completed. Many SNF types have been shipped and received, certain items have already been partially or totally completed for some fuel types. Therefore, when the schedules and tables are generated for each specific fuel type, the state of present preparedness will be entered into the tables and schedules to reflect the current conditions. For example: Full Operational Readiness Reviews (ORRs) (Tables S15 and R15) may not be required; for SNF that has already been shipped, the equipment for shipping and receiving may already be in existence; the shipping path may already be identified; casks may exist with current CofCs and SARPs for the SNF to be shipped, etc. This would lead to large reductions in the time, scope, and cost of other activities such as Project Management (S02-04 and R02-04), Plant and System Activation (S03-02, S03-03, R03-02, R0303), the Transportation Plan (S04-04) and Material Procurement (R11-02). Therefore, the time and cost required to ship a particular SNF may be significantly less than is shown when the current state of conditions is considered. 
Table 1 is the summary table showing the duration, sum of the weeks of the activities, and the costs for each table and the entire program. With parallel activities occurring and with the tie points between activities producing hold points, the duration may be different than the sum of the weeks of the activities given in the tables. In Table 1, the total duration for the program is less than the sum of the activity weeks, because the parallel nature of the activities overwhelms the adverse effects of the hold points.

The detailed tables (J01 to S5B) for this example are made up of five columns: table number/item number, descriptions, time, and cost. The total line for each table also lists the duration for that table. The table number/item number gives the table and the item number for the particular activity. This numbering system allows the user to easily tie the tables and the schedules together. The description column gives the description of the activity for each table entry.

The activities are divided into two classes: those that are typically required for all fuel shipments, and those that are not required or vary significantly from site to site or fuel type to fuel type. The typical activities generally have a narrow range of duration with the assumed value for the step close to the middle of the given range. The atypical activities have larger ranges with the assumed value of the activity often at one end of the range due to some atypical cases.

The time column has two sets of numbers. The first number is the assumed time for each activity. The range (given in the parenthesis) is the low and high ends of the times that the activity could require for any fuel type at any site. The attached tables and schedules were developed using these times.

Costs for each activity has been estimated based on past experience and the latest cost estimates. Costs for each table have been subtotaled so the costs for each group of activities can clearly be seen and understood. Both the time and cost numbers are based on the experience and data from performing SNF shipments and receipts at the INEL, the Hanford Site, the Savannah River Site, and the Oak Ridge National Engineering Laboratory.

The schedules show how all the items tie together. The summary schedule rolls up the detailed schedules for an easy and concise overview. Detailed schedules, including for the cask and dual purpose cask, and the MPC and the special purpose MPC purchase schedules, replicate the interval durations of the tables and show the dependant, consecutive, and concurrent relationships, and interrelationships of SNF shipping activities. Schedules are also a good visual tool for time and cost planning and other programs and tasks. Time is shown in the schedule in month and year-long increments and listed (per the tables) with durations in weeks. Electronic versions of the tables and schedules are available by disk or E-mail to interested users. Dates will not be established until detailed schedules are developed for each site, and agreements-are reached with operations personnel that meet requirements of the agreement between the State of Idaho, the Navy, and DOE. 
The MPC is a canister that is being considered by Office of Civilian Radioactive Waste Management (OCRWM) for transportation, interim storage and disposal of SNF in the Repository. DOE-EM will also dispose of the DOE owned fuel in approved disposal canisters, these will be the DPCs, MPCs or the special purpose MPCs. Making a special purpose MPC may be as simple as installing a different basket in a MPC or as complex as designing and procuring a canister(s)/cask(s) that would meet the repository SNF acceptance criteria. 
Table 1. Generic SNF shipment summary table

\section{Table \#}

Description

Table J01. Joint shipper/receiver preparations

Table S02. General preparation, shipper

Table R02. General preparation, receiver

Table S03. Plant/system activation, shipper

Table R03. Plant/system activation, receiver

Table S04. Transportation issues, shipper

Table S06. ORR/RA preparations, shipper

Table R06. ORR/RA preparation, receiver

Table S07. CSEs \& SAR upgrades, shipper

Table R07. CSEs and SAR upgrades, receiver

Table S08. Environmental, shipper

Table R08. Environmental, receiver

Table S09. SNF Preparation - canister fabrication \& loading, shipper

Table S10. Canister to cask loading equipment design and fabrication, shipper

Table R10. Canister from cask loading equipment design and fabrication, receiver

Table S11. Cask handling equipment design and fabrication, shipper

Table R11. Cask handling equipment design and fabrication, receiver

Table S12. Procedure writing, shipper

Table R12. Procedure writing, receiver

Table S13. Operator training, shipper

Table R13. Operator training, receiver

Table S14. ORR/RA, shipper

Table R14. ORR/RA, receiver

Table S15. DOE ORR, facility fuel transfer, shipper

Table R15. DOE ORR, facility fuel transfer, receiver

Table S16. Joint efforts, shipper

Table R16. Joint efforts, receiver

\begin{tabular}{|c|c|c|c|}
\hline Table R16. Joint efforts, receiver & 2 & 2 & 18 \\
\hline TOTAL & 288 & $1728(949-39526)$ & 6,199 \\
\hline Table S5A. Cask procurement by DOE for SNF shipments & 124 & 210 & 2,738 \\
\hline Table S5B. DPC/MPC or special purpose MPC procurement by DOE for SNF shipments & 124 & 210 & 1,038 \\
\hline
\end{tabular}

\section{Duration Sum of Activity Cost \\ (wk) \\ Times (wk)}

(\$K) 


\section{TABLES J01-R16. GENERIC TABLES OF ACTIVITIES FOR PREPARING SNF FOR INTER-SITE SHIPMENTS}

\section{Joint Shipper/Receiver Preparations}

Table J01 covers the initial activities that are required to start the shipment planning and preparations. Due to the nature of these activities both sites must work intimately together to insure that the program will start and continue on the path that will meet the requirements of both shipper and receiver.

Table J01. Joint shipper/receiver preparations.

\begin{tabular}{|c|c|c|c|}
\hline $\begin{array}{l}\text { Table \# } \\
\text {-Item \# }\end{array}$ & Description & $\begin{array}{l}\text { Time } \\
\text { (wk) }\end{array}$ & $\begin{array}{l}\text { Cost } \\
(\$ K)\end{array}$ \\
\hline J01-01 & $\begin{array}{l}\text { DOE notification for planning for specific SNF } \\
\text { shipments }\end{array}$ & 0 & 0 \\
\hline J01-02 & Develop responsibility assignment matrix & $(1-4)$ & 6 \\
\hline J01-03 & $\begin{array}{l}\text { Receiver prepare, update, and issue fuel acceptance } \\
\text { Criteria (FAC) Based on the Intended Storage Facility }\end{array}$ & $(0-52)$ & 25 \\
\hline J01-04 & $\begin{array}{l}\text { Shipper characterizes SNF to be shipped and complete } \\
\text { FAC for receiver approval }\end{array}$ & $12(4-104)$ & 6 \\
\hline J01-05 & Select cask $\&$ backup cask and facilities* & $(8-26)$ & 40 \\
\hline J01-06 & Prepare joint shipping/receiving plan & $18(12-26)$ & 10 \\
\hline J01-07 & Joint agreement on shipping/receiving plan & $(4-13)$ & 5 \\
\hline J01-08 & Cask selected & 0 & 0 \\
\hline J01-09 & DOE/lease/ or buy decision of cask & 0 & 0 \\
\hline J01-10 & Determine number of cask shipments & $(4-13)$ & 12 \\
\hline J01-11 & Cask scheduling and availability & $(4-13)$ & 3 \\
\hline \multicolumn{2}{|c|}{ Table J01 Sum of activities and costs [Duration $=50$ weeks]: } & $69(37-251)$ & 107 \\
\hline
\end{tabular}

* The term cask also includes the dual purpose cask (DPC), the multi-purpose canister (MPC) or the special purpose MPC. Tables S5A describes the activities for the procurement of a cask, Table S5B describes the activities for the procurement of a DPC or a MPC (standard or special). 


\section{General Preparation, Shipper}

Table S02, general preparations by the shipper, covers basic activities that are required for the shipper to start the SNF shipping task, i.e., the shipper's budget, change board approval, and project and management plans.

Table S02. General preparation, shipper.

\begin{tabular}{|c|c|c|c|}
\hline $\begin{array}{l}\text { Table \# } \\
\text {-Item \# }\end{array}$ & Description & $\begin{array}{l}\text { Time } \\
\text { (wk) }\end{array}$ & $\begin{array}{l}\text { Cost } \\
(\$ K)\end{array}$ \\
\hline S02-01 & Revise schedule/budget plan request & $(2-4)$ & 3 \\
\hline S02-02 & Change control board (CCB) approved - SNF transfers offsite & 0 & 0 \\
\hline S02-03 & Update project plan & $4 \quad(2-12)$ & 3 \\
\hline S02-04 & Project management & $191(52-208)$ & 453 \\
\hline \multicolumn{2}{|c|}{ Table S02 Sum of activities and costs [Table S02 Duration $=230$ weeks]: } & $198(56-224)$ & 459 \\
\hline
\end{tabular}

\section{General Preparation, Receiver}

Table R02, general preparations by the receiver, covers basic activities that are required for the receiver to start the SNF shipping task, i.e., the receiver's budget, change board approval, and project and management plans.

Table R02. General preparation, receiver.

\begin{tabular}{llcrr}
$\begin{array}{c}\text { Table \# - } \\
\text { Item \# }\end{array}$ & \multicolumn{1}{c}{ Description } & \multicolumn{1}{c}{$\begin{array}{c}\text { Time } \\
(\mathrm{wk})\end{array}$} & $\begin{array}{r}\text { Cost } \\
(\text { (\$K) }\end{array}$ \\
\hline R02-01 & Revise schedule/budget plan request & 3 & $(2-4)$ & 3 \\
R02-02 & CCB approved - SNF transfers offsite & 0 & 0 \\
R02-03 & Update project plan & 4 & $(2-12)$ & 3 \\
R02-04 & Project management & $191(52-208)$ & 413 \\
R02-05 & Prepare inspection plan for fuel storage & $13 \quad(8-26)$ & 10 \\
\hline Table R02 Sum of activities and costs [Duration = 234 weeks]: & $211(64-250)$ & 429 \\
\hline
\end{tabular}




\section{Plant/System Activation, Shipper}

Table S03, the plant and system reactivation table for the shipper, covers activities that are required to bring a wholly or partially deactivated or mothballed plant or system of the shipper back to the condition required for preparation of and shipment of SNF. This table is zeroed out for facilities that are not wholly or partially deactivated or mothballed.

Table S03. Plant/system activation, shipper.

\begin{tabular}{clcr}
\hline $\begin{array}{c}\text { Table \# - } \\
\text { Item \# }\end{array}$ & \multicolumn{1}{c}{ Description } & $\begin{array}{c}\text { Time } \\
(\text { wk })\end{array}$ & $\begin{array}{r}\text { Cost } \\
(\$ \mathrm{~K})\end{array}$ \\
\hline S03-01 & Start staffing increase & 0 & 0 \\
S03-02 & Increase staff and train for SNF transfers offsite & $44(26-52)$ & 379 \\
S03-03 & Facility/equipment mods/upgrades/refurbish \& tests & $44(26-52)$ & 397 \\
\hline Table S03 Sum of activities and costs [ Duration $=45$ weeks]: & $88(52-104)$ & 776 \\
\hline
\end{tabular}

\section{Plant/System Activation, Receiver}

Table R03, the plant and system reactivation table for the receiver, covers the activities that are required to bring a wholly or partially deactivated or mothballed plant or system of the receiver back to the condition required for the preparation of and the receipt of SNF. This table is zeroed out for facilities that are not wholly or partially deactivated or mothballed.

Table R03. Plant/system activation, receiver.

\begin{tabular}{lllr}
\hline $\begin{array}{c}\text { Table \# - } \\
\text { Item \# }\end{array}$ & \multicolumn{1}{c}{ Description } & \multicolumn{1}{c}{$\begin{array}{c}\text { Time } \\
\text { (wk) }\end{array}$} & $\begin{array}{r}\text { Cost } \\
\text { (\$K) }\end{array}$ \\
\hline R03-01 & Start staffing increase & 0 & 0 \\
R03-02 & Increase staff \& train for SNF transfers from offsite & $44(26-52)$ & 379 \\
R03-03 & Facility/equipment mods/upgrades/refurbish and tests & $44(26-52)$ & 397 \\
\hline Table R03 Sum of activities and costs [Duration = 45 weeks]: & $88(52-104)$ & 776 \\
\hline
\end{tabular}




\section{Transportation Issues, Shipper}

Table S04, the transportation issues table for the shipper, covers one of the main bodies of work and costs of preparing for a SNF shipment campaign. It covers leasing a cask, getting it permitted (SARP and $\mathrm{CofC}$ ) for the SNF to be shipped, developing the transportation plan, determining shipping route, getting permits and approvals for shipment, making notification, and start of actual shipments.

Table S04. Transportation issues, shipper.

\begin{tabular}{llrrr}
$\begin{array}{r}\text { Table \# } \\
\text {-Item \# }\end{array}$ & \multicolumn{1}{c}{ Description } & \multicolumn{2}{c}{$\begin{array}{c}\text { Time } \\
(\mathrm{wk})\end{array}$} & $\begin{array}{r}\text { Cost } \\
\text { (\$K) }\end{array}$ \\
\hline S04-01 & Lease cask and commit funds & 12 & $(2-13)$ & 500 \\
S04-02 & Cask safety analysis report for packaging (SARP) amendment & 50 & $(26-78)$ & 150 \\
S04-03 & Cask certificate of compliance (CofC) amendment & 31 & $(26-104)$ & 72 \\
S04-04 & Transportation plan and related issues & 100 & $(26-104)$ & 500 \\
S04-05 & Crane and rail load test \& PMs & 5 & $(4-8)$ & 6 \\
S04-06 & Cask shipment route determination \& approval & 18 & $(16-26)$ & 50 \\
S04-07 & Fuel shipment permits & 18 & $(12-26)$ & 50 \\
S04-08 & Shipment notifications & 1 & $(1-2)$ & 3 \\
S04-09 & Fuel shipment approvals by DOE & 1 & $(1-2)$ & 0 \\
S04-10 & Initiate fuel shipment(s) & 0 & & 0 \\
S04-11 & Selected cask available for use (window of availability) & 0 & 0 \\
\hline Table S04 Sum of activities and costs [Duration = 228 weeks]: & $236(114-363)$ & 1331 \\
\hline
\end{tabular}




\section{ORR/RA Preparations, Shipper}

Table S06 covers the paper work that certifies that the shipper's facilities are ready for SNF preparation and shipment. This is accomplished through the Operational Readiness Review/Readiness Accessment $(\mathrm{RA})$ process and implemented by the Plan-of-Action, $R A$ team, Implementation Plan and leads to the Certification of Readiness.

Table S06. ORR/RA preparations, shipper.

\begin{tabular}{llccr}
\hline $\begin{array}{c}\text { Table \# } \\
\text {-Item \# }\end{array}$ & \multicolumn{1}{c}{ Description } & \multicolumn{2}{c}{$\begin{array}{c}\text { Time } \\
(\text { wk })\end{array}$} & $\begin{array}{r}\text { Cost } \\
(\$ \mathrm{~K})\end{array}$ \\
\hline S06-01 & Department self assessment for readiness assessment & 13 & $(8-26)$ & 48 \\
S06-02 & Prepare plan-of-action (POA) & 5 & $(4-8)$ & 17 \\
S06-03 & Appoint readiness assessment (RA) team & 2 & $(1-3)$ & 1 \\
S06-04 & DOE review POA & 2 & $(1-3)$ & 0 \\
S06-05 & Train RA team & 2 & $(1-3)$ & 29 \\
S06-06 & Prepare implementation plan (IP) & 4 & $(2-8)$ & 50 \\
S06-07 & DOE review IP & 2 & $(1-3)$ & 0 \\
S06-08 & Department certification of readiness & 10 & $(4-26)$ & 48 \\
S06-09 & RA resolution of comments & 4 & $(2-5)$ & 12 \\
\hline Table S06 Sum of activities and costs [Duration $=27$ weeks]: & $44(24-85)$ & 205 \\
\hline
\end{tabular}




\section{ORR/RA Preparation, Receiver}

Table R06 covers the paper work that certifies that the receiver's facilities are ready for the SNF preparation and receipt. This is accomplished through the Operational Readiness Review/Readiness Accessment (RA) process and implemented by the Plan-of-Action, RA team, Implementation Plan and leads to the Certification of Readiness.

Table R06. ORR/RA preparation, receiver.

\begin{tabular}{llcr}
$\begin{array}{c}\text { Table \# } \\
\text {-Item \# }\end{array}$ & \multicolumn{1}{c}{ Description } & $\begin{array}{c}\text { Time } \\
(\mathrm{wk})\end{array}$ & $\begin{array}{r}\text { Cost } \\
(\$ \mathrm{~K})\end{array}$ \\
\hline R06-01 & Department self assessment for RA & $13(8-26)$ & 48 \\
R06-02 & Prepare plan-of-action & $5(4-8)$ & 17 \\
R06-03 & Appoint RA team & $2(1-3)$ & 1 \\
R06-04 & DOE review POA & $2(1-3)$ & 0 \\
R06-05 & Train RA team & $2(1-3)$ & 29 \\
R06-06 & Prepare implementation plan & $4(2-8)$ & 50 \\
R06-07 & DOE review IP & $2(1-3)$ & 0 \\
R06-08 & Department certification of readiness & $10(4-26)$ & 48 \\
R06-09 & RA resolution of comments & $4(2-5)$ & 12 \\
\hline Table R06 Sum of activities and costs [Duration $=27$ weeks]: & $44(24-85)$ & 205 \\
\hline
\end{tabular}




\section{CSEs \& SAR Upgrades, Shipper}

Table S07 covers upgrades to criticality and safety documents for the shipper that will have to be upgraded and approved before fuel can be prepared and shipped. This activity requires DOE and independent approvals.

Table S07. CSEs and SAR upgrades, shipper.

\begin{tabular}{llrrr}
\hline $\begin{array}{l}\text { Table \# } \\
\text {-Item \# }\end{array}$ & \multicolumn{1}{c}{ Description } & \multicolumn{1}{c}{$\begin{array}{c}\text { Time } \\
\text { (wk) }\end{array}$} & $\begin{array}{r}\text { Cost } \\
\text { (\$K) }\end{array}$ \\
\hline S07-01 & Prepare primary criticality safety evaluation (CSE) & 13 & $(12-26)$ & 40 \\
S07-02 & Update facility fuel list & 3 & $(1-6)$ & 3 \\
S07-03 & Prepare independent CSE & 13 & $(12-26)$ & 10 \\
S07-04 & Review CSEs/technical specification (TS) update & 3 & $(2-4)$ & 18 \\
S07-05 & Resolve CSEs/TS comments/technical review & 5 & $(4-12)$ & 15 \\
S07-06 & Radiation and environmental safety committee (RESC) review & 2 & $(1-4)$ & 6 \\
S07-07 & Resolve RESC comments & 2 & $(1-4)$ & 6 \\
S07-08 & Environmental safety and health (ES\&H) review & 1 & $(1-3)$ & 6 \\
S07-09 & Resolve ES\&H comments & 3 & $(2-6)$ & 10 \\
S07-10 & DOE review and comments for approval & $13(12-26)$ & 0 \\
S07-11 & Resolve DOE comments for DOE approval & 5 & $(4-8)$ & 0 \\
S07-12 & Independent procedure validation & 6 & $(4-8)$ & 15 \\
\hline Table S07 Sum of activities and costs [Duration $=62$ weeks]: & $69(56-133)$ & 129 \\
\hline
\end{tabular}




\section{CSEs and SAR Upgrades, Receiver}

Table R07 covers the upgrades to the criticality and safety documents for the receiver that will have to be upgraded and approved before the fuel can be received. This activity requires DOE and independent approvals.

Table R07. CSEs and SAR upgrades, receiver.

\begin{tabular}{|c|c|c|c|}
\hline $\begin{array}{l}\text { Table \# } \\
\text {-Item \# }\end{array}$ & Description & $\begin{array}{l}\text { Time } \\
\text { (wk) }\end{array}$ & $\begin{array}{l}\text { Cost } \\
(\$ K)\end{array}$ \\
\hline R07-01 & Prepare primary criticality safety evaluation & $13(12-26)$ & 40 \\
\hline R07-02 & Update facility fuel list & $30(26-78)$ & 29 \\
\hline R07-03 & Prepare Independent CSE & $13(12-26)$ & 10 \\
\hline R07-04 & Review CSEs/technical specification update & $3(2-4)$ & 18 \\
\hline R07-05 & Resolve CSEs/TS comments/technical review & $5 \quad(4-12)$ & 15 \\
\hline R07-06 & Radiation and environmental safety committee review & $(1-4)$ & 6 \\
\hline R07-07 & Resolve RESC comments & $(1-4)$ & 6 \\
\hline R07-08 & Environmental safety and health review & $(1-3)$ & 6 \\
\hline R07-09 & Resolve environmental safety and health comments & $(2-6)$ & 10 \\
\hline R07-10 & DOE review and comments for approval & $13(12-26)$ & 0 \\
\hline R07-11 & Resolve DOE comments for DOE approval & $(4-8)$ & 0 \\
\hline R07-12 & Independent procedure validation & $(4-8)$ & 15 \\
\hline \multicolumn{2}{|c|}{ Table R07 Sum of activities and costs [Duration $=82$ weeks]: } & $96(81-205)$ & 155 \\
\hline
\end{tabular}

\section{Environmental, Shipper}

Table S08 covers NEPA compliance issues the shipper needs to insure that all environmental issues are addressed and taken care of before the shipper can prepare and ship the fuel.

Table S08. Environmental, shipper.

\begin{tabular}{lccr}
\hline $\begin{array}{l}\text { Table \# } \\
\text {-Item \# }\end{array}$ & Description & $\begin{array}{l}\text { Time } \\
(\mathrm{wk})\end{array}$ & $\begin{array}{r}\text { Cost } \\
(\$ \mathrm{~K})\end{array}$ \\
\hline S08-01 Review NEPA compliance issues & $18(12-52)$ & 12 \\
\hline Table S08 Sum of activities and costs [Duration $=18$ weeks]: & $18(12-52)$ & 12 \\
\hline
\end{tabular}




\section{Environmental, Receiver}

Table R08 covers the NEPA compliance issues the receiver needs to insure that all environmental issues are addressed and taken care of before the receiver can receive the fuel.

Table R08. Environmental, receiver.

\begin{tabular}{lccr}
\hline Table \# -Item \# & Description & Time (wk) & Cost (\$K) \\
\hline R08-01 & Review NEPA compliance issues & $18(12-52)$ & 12 \\
\hline Table R08 Sum of activities and costs [Duration = 18 weeks]: & $18(12-52)$ & 12 \\
\hline
\end{tabular}




\section{SNF Preparation - Canister Fabrication}

Table S09 covers activities that prepare fuel for shipment. The first crucial step is obtaining sufficient data to meet the fuel receipt criteria of the receiver, then the equipment to fabricate the fuel canisters is designed, constructed, tested and turned over for use. This is the first table in which the material costs are significant. In the tables for which the material costs are significant, such as material procurement, the activity costs are broken into labor costs and material costs (Mat).

Table S09. SNF Preparation - canister fabrication \& loading, shipper

\begin{tabular}{|c|c|c|c|}
\hline Table \# -Item & Description & Time (wk) & Cost (\$K) \\
\hline S09-01 & SNF fuel handling and shipping characterization data & $25(12-104)$ & 40 \\
\hline S09-02 & Determine equipment requirements & $12 \quad(8-26)$ & 5 \\
\hline S09-03 & Identify/design equipment & $13(12-39)$ & 20 \\
\hline S09-04 & Procure material & $13(12-26)$ & Mat $^{*} 10$ \\
\hline S09-05 & Planning for equipment fabrication & $(8-12)$ & 6 \\
\hline S09-06 & Equipment fabrication & $25(12-52)$ & 10 \\
\hline S09-07 & Equipment checkout & $9 \quad(2-26)$ & 11 \\
\hline S09-08 & Closeout for equipment fabrication & $(1-8)$ & 2 \\
\hline S09-09 & As-Bilt for fabricated equipment & $(2-16)$ & 6 \\
\hline \multicolumn{2}{|c|}{ Table S09 Sum of activities and costs [Duration $=204$ weeks] } & $\begin{array}{r}116 \\
(69-309)\end{array}$ & 120 \\
\hline
\end{tabular}

* Mat-Raw material, specialized equipment, etc., cost in addition to labor cost. 


\section{Canister To Cask Loading Equipment Design and Fabrication, Shipper}

Table S10 covers activities that prepare fuel for shipment. The first crucial step is using sufficient data to meet the fuel receipt criteria of the receiver to design, construct, test and turn over for use equipment to load the SNF canister into the shipping cask.

Table S10. Canister to cask loading equipment design and fabrication, shipper.

\begin{tabular}{llcrr}
$\begin{array}{r}\text { Table \# } \\
\text {-Item \# }\end{array}$ & \multicolumn{1}{c}{ Description } & \multicolumn{1}{c}{$\begin{array}{c}\text { Time } \\
(\mathrm{wk})\end{array}$} & $\begin{array}{r}\text { Cost } \\
\text { (\$K) }\end{array}$ \\
\hline S10-01 & Identify/design equipment & 18 & $(12-52)$ & 25 \\
S10-02 & Procure material & 12 & $(8-26)$ & 18 \\
& & 4 & $(2-26)$ & Mat 25 \\
S10-03 & Planning for equipment fabrication & $13(12-52)$ & 20 \\
S10-04 & Equipment fabrication & 4 & $(2-26)$ & 6 \\
S10-05 & Equipment checkout & 2 & $(2-8)$ & 3 \\
S10-06 & Closeout for equipment fabrication & 5 & $(4-16)$ & 6 \\
S10-07 & As-Build for fabricated equipment & $58(42-206)$ & 106 \\
\hline Table S10 Sum of activities and cost [Duration $=101$ weeks]: & & \\
\hline
\end{tabular}




\section{Canister From Cask Loading Equipment Design and Fabrication, Receiver}

Table R10 covers activities that prepare fuel for shipment. The first crucial step is using the design of the canister which the shipper designed to meet the fuel receipt criteria of the receiver to design, construct, test and turn-over for use the equipment to unload the SNF canister into the shipping cask.

Table R10. Canister from cask loading equipment design and fabrication, receiver.

\begin{tabular}{|c|c|c|c|}
\hline $\begin{array}{l}\text { Table \# } \\
\text {-Item \# }\end{array}$ & Description & $\begin{array}{l}\text { Time } \\
\text { (wk) }\end{array}$ & $\begin{array}{l}\text { Cost } \\
(\$ K)\end{array}$ \\
\hline R10-01 & Identify/design equipment & $18(12-52)$ & 25 \\
\hline R10-02 & Procure material & $12(8-26)$ & $\begin{array}{r}18 \\
\text { Mat } 25\end{array}$ \\
\hline R10-03 & Planning for equipment fabrication & $4 \quad(2-26)$ & 3 \\
\hline R10-04 & Equipment fabrication & $13(12-52)$ & 20 \\
\hline $\mathrm{R} 10-05$ & Equipment checkout & $4 \quad(2-26)$ & 6 \\
\hline R10-06 & Closeout for equipment fabrication & $2 \quad(2-8)$ & 3 \\
\hline R10-07 & As-Build for fabricated equipment & $5(4-16)$ & 6 \\
\hline \multicolumn{2}{|c|}{ Table R10 Sum of Activities and costs [Duration $=101$ weeks]: } & $58(42-206)$ & 106 \\
\hline
\end{tabular}




\section{Cask Handling Equipment Design and Fabrication, Shipper}

Table S11 covers the activities that prepares the fuel for shipment. The first crucial step is using the data on the canister design and the cask that has been selected to ship the SNF to meet the fuel receipt criteria of the receiver to design, construct, test and turn-over for the equipment for the shipper to handle the shipping cask.

Table S11. Cask handling equipment design and fabrication, shipper.

\begin{tabular}{|c|c|c|c|}
\hline $\begin{array}{l}\text { Table \# } \\
\text {-Item \# }\end{array}$ & Description & $\begin{array}{l}\text { Time } \\
\text { (wk) }\end{array}$ & $\begin{array}{l}\text { Cost } \\
(\$ K)\end{array}$ \\
\hline S11-01 & Identify/design equipment - cask handling/transport loading & $18(12-52)$ & 14 \\
\hline S11-02 & Procure material & $\begin{array}{ll}13 & (6-26) \\
& \end{array}$ & $\begin{array}{r}10 \\
\text { Mat } 145\end{array}$ \\
\hline S11-03 & Planning for equipment fabrication & $(2-26)$ & 2 \\
\hline S11-04 & Equipment fabrication & $13(12-52)$ & 20 \\
\hline S11-05 & Equipment checkout & $(2-26)$ & 5 \\
\hline S11-06 & Closeout for equipment fabrication & $(2-8)$ & 3 \\
\hline S11-07 & As-Build for fabricated equipment & $(2-8)$ & 6 \\
\hline \multicolumn{2}{|c|}{ Table S11 Sum of activities and costs [Duration $=102$ weeks]: } & $59(38-198)$ & 205 \\
\hline
\end{tabular}




\section{Cask Handling Equipment Design and Fabrication, Receiver}

Table R11 covers the activities that prepares the fuel for shipment. The first crucial step is using the data on the canister design and the cask that has been selected to ship the SNF to meet the fuel receipt criteria of the receiver to design, construct, test and turn-over for the equipment for the receiver to handle the shipping cask.

Table R11. Cask handling equipment design and fabrication, receiver.

\begin{tabular}{llrrr}
\hline $\begin{array}{r}\text { Table \# } \\
\text {-Item \# }\end{array}$ & \multicolumn{1}{c}{ Description } & \multicolumn{1}{c}{$\begin{array}{c}\text { Time } \\
(\mathrm{wk})\end{array}$} & $\begin{array}{r}\text { Cost } \\
(\$ \mathrm{~K})\end{array}$ \\
\hline R11-01 & $\begin{array}{l}\text { Identify/design equipment - cask handling/transport } \\
\text { loading }\end{array}$ & $18(12-52)$ & 14 \\
R11-02 & Procure material & 13 & $(6-26)$ & 10 \\
& & 4 & $(2-26)$ & 2 \\
R11-03 & Planning for equipment fabrication & $13(12-52)$ & 20 \\
R11-04 & Equipment fabrication & 4 & $(2-26)$ & 5 \\
R11-05 & Equipment checkout & 2 & $(2-8)$ & 3 \\
R11-06 & Closeout for equipment fabrication & 5 & $(2-8)$ & 6 \\
R11-07 & As-Build for fabricated equipment & $59(38-198)$ & 205 \\
\hline Table R11 Sum of activities and costs [Duration $=97$ weeks]: & & & \\
\hline
\end{tabular}

\section{Procedure Writing, Shipper}

Table S12 covers the procedure writing, updates, validation and comment resolutions that will be required to ship the SNF.

Table S12. Procedure writing, shipper.

\begin{tabular}{|c|c|c|c|}
\hline $\begin{array}{l}\text { Table \# } \\
\text {-Item \# }\end{array}$ & Description & $\begin{array}{l}\text { Time } \\
\text { (wk) }\end{array}$ & $\begin{array}{l}\text { Cost } \\
(\$ K)\end{array}$ \\
\hline S12-01 & Develop and update procedures & $30(26-104)$ & 30 \\
\hline S12-02 & Validate procedures & $(4-26)$ & 10 \\
\hline S12-03 & Procedure reviews \& resolution of comments & $(2-8)$ & 5 \\
\hline \multicolumn{2}{|c|}{ Table S12 Sum of activities and costs [Duration $=43$ weeks]: } & $42(32-138)$ & 45 \\
\hline
\end{tabular}




\section{Procedure Writing, Receiver}

Table R12 covers the procedure writing, updates, validation and comment resolutions that will be required to receive the SNF.

Table R12. Procedure writing, receiver.

\begin{tabular}{|c|c|c|c|}
\hline $\begin{array}{l}\text { Table \# } \\
\text {-Item \# }\end{array}$ & Description & $\begin{array}{l}\text { Time } \\
\text { (wk) }\end{array}$ & $\begin{array}{l}\text { Cost } \\
\text { (\$K) }\end{array}$ \\
\hline R12-01 & Develop and update procedures & $30(26-104)$ & 30 \\
\hline R12-02 & Validate procedures & $(4-26)$ & 10 \\
\hline R12-03 & Procedure reviews \& resolution of comments & $(2-8)$ & 5 \\
\hline \multicolumn{2}{|c|}{ Table R12 Sum of activities and costs [Duration $=43$ weeks]: } & $42(32-138)$ & 45 \\
\hline
\end{tabular}

\section{Operator Training, Shipper}

Table S13 cover the preparation for and the training of the operators that will be required for shipment of the SNF.

Table S13. Operator training, shipper.

\begin{tabular}{|c|c|c|c|}
\hline $\begin{array}{l}\text { Table \# } \\
\text {-Item \# }\end{array}$ & Description & $\begin{array}{l}\text { Time } \\
\text { (wk) }\end{array}$ & $\begin{array}{l}\text { Cost } \\
(\$ \mathrm{~K})\end{array}$ \\
\hline S13-01 & Preparations for training & $4 \quad(2-8)$ & 12 \\
\hline S13-02 & Training (20 hours for 2 Crews) & $6 \quad(2-8)$ & 18 \\
\hline \multicolumn{2}{|c|}{ Table S13 Sum of activities and costs [Duration $=10$ weeks]: } & $10(4-16)$ & 30 \\
\hline
\end{tabular}

\section{Operator Training, Receiver}

Table R13 cover the preparation for and the training of the operators that will be required for receipt of the SNF.

Table R13. Operator training, receiver.

\begin{tabular}{llllr}
\hline $\begin{array}{l}\text { Table \# } \\
\text {-Item \# }\end{array}$ & \multicolumn{1}{c}{ Description } & $\begin{array}{l}\text { Time } \\
(\mathrm{wk})\end{array}$ & $\begin{array}{r}\text { Cost } \\
(\text { (SK) }\end{array}$ \\
\hline R13-01 & Preparations for training & 4 & $(2-8)$ & 12 \\
R13-02 & Training (20 hours for 2 Crews) & $6(2-8)$ & 18 \\
\hline Table R13 Sum of activities and costs [Duration $=10$ weeks]: & $10(4-16)$ & 30 \\
\hline
\end{tabular}




\section{ORR/RA, Shipper}

Table S14 covers the shipper's dry run of the fuel handling and resulting readiness assessment, RA report, closure of the prestart findings, and the approval for the shipper to start operation.

Table S14. ORR/RA, shipper.

\begin{tabular}{|c|c|c|c|}
\hline $\begin{array}{l}\text { Table \# } \\
\text {-Item \# }\end{array}$ & Description & $\begin{array}{l}\text { Time } \\
\text { (wk) }\end{array}$ & $\begin{array}{l}\text { Cost } \\
(\$ \mathrm{~K})\end{array}$ \\
\hline S14-01 & Dry run for fuel handling & $1 \quad(1-8)$ & 18 \\
\hline S14-02 & Readiness assessment & $8(4-12)$ & 140 \\
\hline S14-03 & Prepare final report & $4(2-12)$ & 66 \\
\hline S14-04 & Closure of prestart findings & $5(4-12)$ & 8 \\
\hline S14-05 & Approval to start operation & $5(4-12)$ & 16 \\
\hline S14-06 & Ready for receipt/shipment of fuel & 0 & 0 \\
\hline \multicolumn{2}{|c|}{ Table S14 Sum of Activities and Costs [Duration $=24$ weeks]: } & $23(15-56)$ & 248 \\
\hline
\end{tabular}

\section{ORR/RA, Receiver}

Table R14 covers the receiver's dry run of the fuel handling and resulting readiness assessment, RA report, closure of the prestart findings, and the approval for the receiver to start operation.

Table R14. ORR/RA, Receiver.

\begin{tabular}{lllr}
$\begin{array}{r}\text { Table \# } \\
\text {-Item \# }\end{array}$ & \multicolumn{1}{c}{ Description } & \multicolumn{1}{c}{$\begin{array}{c}\text { Time } \\
(\mathrm{wk})\end{array}$} & $\begin{array}{r}\text { Cost } \\
(\$ \mathrm{~K})\end{array}$ \\
\hline R14-01 & Dry run for fuel handling & 1 & $(1-8)$ \\
R14-02 & Readiness assessment & $8(4-12)$ & 18 \\
R14-03 & Prepare final report & $4(2-12)$ & 66 \\
R14-04 & Closure of prestart findings & $5(4-12)$ & 8 \\
R14-05 & Approval to start operation & $5(4-12)$ & 16 \\
R14-06 & Ready for receipt/shipment of fuel & 0 & 0 \\
\hline Table R14 Sum of activities and costs [Duration $=24$ weeks]: & $23(15-56)$ & 248 \\
\hline
\end{tabular}




\section{DOE ORR, Facility Fuel Transfer, Shipper}

Table S15 covers the DOE ORR for facility fuel transfer for the shipper. This includes the preparedness preparation and drill, the DOE ORR, the final report preparation, closure of the prestart findings, and the approval for the shipper to operate.

Table S15. DOE ORR, facility fuel transfer, shipper.

\begin{tabular}{lllll}
\hline $\begin{array}{r}\text { Table \# } \\
\text {-Item \# }\end{array}$ & \multicolumn{1}{c}{ Description } & \multicolumn{2}{c}{ Time } & \multicolumn{2}{c}{$\begin{array}{c}\text { Cost } \\
\text { (wk) }\end{array}$} & (\$K) \\
\hline S15-01 & Emergency preparedness preparation & 4 & $(3-8)$ & 12 \\
S15-02 & Emergency preparedness drill & 1 & $(1-2)$ & 18 \\
S15-03 & DOE ORR & 6 & $(3-8)$ & 10 \\
S15-04 & DOE final report preparation & 4 & $(3-6)$ & 12 \\
S15-05 & Closure of prestart findings & 4 & $(3-6)$ & 30 \\
S15-06 & Approval to operate & 1 & $(1-2)$ & 3 \\
\hline Table S15 Sum of activities and costs [Duration $=25$ weeks]: & $20(14-32)$ & 85 \\
\hline
\end{tabular}

\section{DOE ORR, Facility Fuel Transfer, Receiver}

Table R15 covers the DOE ORR for facility fuel transfer for the receiver. This includes the preparedness preparation and drill, the DOE ORR, the final report preparation, closure of the prestart findings, and the approval for the receiver to operate.

Table R15. DOE ORR, facility fuel transfer, receiver.

\begin{tabular}{llllr}
\hline $\begin{array}{r}\text { Table \# } \\
\text {-Item \# }\end{array}$ & \multicolumn{1}{c}{ Description } & \multicolumn{2}{c}{$\begin{array}{c}\text { Time } \\
\text { (wk) }\end{array}$} & $\begin{array}{r}\text { Cost } \\
\text { (\$K) }\end{array}$ \\
\hline R15-01 & Emergency preparedness preparation & 4 & $(3-8)$ & 12 \\
R15-02 & Emergency preparedness drill & 1 & $(1-2)$ & 18 \\
R15-03 & DOE ORR & 6 & $(3-8)$ & 10 \\
R15-04 & DOE final report preparation & 4 & $(3-6)$ & 12 \\
R15-05 & Closure of prestart findings & 4 & $(3-6)$ & 30 \\
R15-06 & Approval to operate & 1 & $(1-2)$ & 3 \\
\hline Table R15 Sum of activities and costs [Duration $=25$ weeks]: & \multicolumn{2}{c}{$20(14-32)$} & 85 \\
\hline
\end{tabular}




\section{Joint Efforts, Shipper}

Table S16 covers the final shipper and receiver schedule agreement, the inspect and PM of the shipping cask, and the actual preparation of the fuel, loading of the cask, and shipment of the fuel.

Table S16. Joint efforts, shipper.

\begin{tabular}{lllr}
\hline $\begin{array}{c}\text { Table \# } \\
\text {-Item \# }\end{array}$ & \multicolumn{1}{c}{ Description } & Time & Cost \\
S16-01 & Shipper/receiver schedule agreement & 3 & $(2-4)$ \\
S16-02 & Inspect and PM cask & $2(1-3)$ & 9 \\
S16-03 & Prepare fuel, load cask, and ship & $2(1-3)$ & 12 \\
\hline Table S16 Sum of activities and costs [Duration $=61$ weeks]: & $7(4-10)$ & 27 \\
\hline
\end{tabular}

\section{Joint Efforts, Receiver}

Table R16 covers the receipt of the shipping cask, off-loading of the fuel, and the cask decontamination and return to the shipper.

Table R16. Joint efforts, receiver.

\begin{tabular}{|c|c|c|c|}
\hline $\begin{array}{l}\text { Table \# } \\
\text {-Item \# }\end{array}$ & Description & $\begin{array}{l}\text { Time } \\
\text { (wk) }\end{array}$ & $\begin{array}{l}\text { Cost } \\
\text { (\$K) }\end{array}$ \\
\hline R16-01 & Receive cask, off-load fuel, and store/process & $1 \quad(1-4)$ & 9 \\
\hline R16-02 & Decontaminate and return empty cask & $1(1-3)$ & 9 \\
\hline \multicolumn{2}{|c|}{ Table R16 Sum of activities and costs [Duration $=2$ weeks]: } & $2(2-7)$ & 18 \\
\hline
\end{tabular}

\section{TOTAL Sum of Activities and Costs:}

Table 17 summarizes the sum of the activities times, costs, and the overall duration.

Table 17. TOTAL Sum of activities and costs:

\begin{tabular}{|c|c|c|}
\hline $\begin{array}{l}\text { Table \# } \\
\text {-Item \# }\end{array}$ & $\begin{array}{l}\text { Time } \\
\text { (wk) }\end{array}$ & $\begin{array}{l}\text { Cost } \\
(\$ K)\end{array}$ \\
\hline TOTAL Sum of activities and costs [Total Duration $=288$ weeks]: & $\begin{array}{c}1685 \\
(974-3598)\end{array}$ & 6405 \\
\hline
\end{tabular}




\section{Cask Procurement by DOE for SNF Shipments}

When the choice is made to procure rather than lease a cask, table S5A is used. This table covers the procurement package, request for proposal, scope of work, design criteria preparation, developing the planning schedule, preparing of revising and the approval of the cask SARP and CofC, developing the inspection plan, bid and awarding the cask contract, and the fabrication and testing of the cask.

Table S5A. Cask procurement by DOE for SNF shipments.

\begin{tabular}{llrrr}
\hline $\begin{array}{l}\text { Table \#- } \\
\text { Item \# }\end{array}$ & \multicolumn{1}{c}{ Description } & \multicolumn{2}{c}{$\begin{array}{c}\text { Time } \\
\text { (wk) }\end{array}$} & \multicolumn{1}{c}{$\begin{array}{c}\text { Cost } \\
\text { (\$K) }\end{array}$} \\
\hline S5A-01 & Prepare procurement package and request for proposal & 4 & $(3-6)$ & 12 \\
S5A-02 & Prepare scope of work & 4 & $(3-6)$ & 12 \\
S5A-03 & Prepare specifications & 4 & $(3-6)$ & 12 \\
S5A-04 & Prepare design criteria & 4 & $(3-6)$ & 12 \\
S5A-05 & Develop planning schedule & 3 & $(2-4)$ & 9 \\
S5A-06 & Prepare/revise SARP for cask & $100(52-230)$ & 500 \\
S5A-07 & Develop inspection plan & 7 & $(5-10)$ & 21 \\
S5A-08 & Bid and award & 4 & $(3-6)$ & 24 \\
S5A-09 & Fabricate cask & 26 & $(20-52)$ & 2,000 \\
S5A-10 & Test cask & 4 & $(3-6)$ & 36 \\
S5A-11 & CofC for cask & 50 & $(26-78)$ & 100 \\
S5A-12 & SARP approval by regulatory agency & 0 & & 0 \\
S5A-13 & CofC approval by regulatory agency & 0 & & 0 \\
\hline Table S5A Sum of activities and costs [Duration = 124 weeks]: & $(123-410)$ & 2,738 \\
\hline
\end{tabular}




\section{DPC, MPC or Special Purpose MPC Procurement by DOE for SNF Shipments}

When the choice is made to procure a dual purpose cask (DPC), multi-purpose cask (MPC), or a special purpose MPC rather than lease a cask, table S5B is used. This table covers the procurement package, request for proposal, scope of work, design criteria preparation, developing the planning schedule, preparing of revising and the approval of the cask SARP and CofC, developing the inspection plan, bid and awarding the DPC/MPC contract, and the fabrication and testing of the DPC/MPC and DPC/MPC overpack.

Table S5B. DPC/MPC or special purpose MPC procurement by DOE for SNF shipments.

\begin{tabular}{llrrr}
\hline $\begin{array}{c}\text { Table \#- } \\
\text { Item \# }\end{array}$ & \multicolumn{1}{c}{ Description } & \multicolumn{1}{c}{$\begin{array}{c}\text { Time } \\
(\mathrm{wk})\end{array}$} & $\begin{array}{r}\text { Cost } \\
(\$ \mathrm{~K})\end{array}$ \\
\hline S5B-01 & Prepare procurement package and request for proposal & 4 & $(3-6)$ & 12 \\
S5B-02 & Prepare scope of work & 4 & $(3-6)$ & 12 \\
S5B-03 & Prepare specifications & 4 & $(3-6)$ & 12 \\
S5B-04 & Prepare design criteria & 4 & $(3-6)$ & 12 \\
S5B-05 & Develop planning Schedule & 3 & $(2-4)$ & 9 \\
S5B-06 & Prepare/revise SARP for DPC/MPC/special purpose & $100(52-230)$ & 150 \\
& MPC & 7 & $(5-10)$ & 21 \\
S5B-07 & Develop inspection plan & 4 & $(3-6)$ & 24 \\
S5B-08 & Bid and award & 26 & $(20-52)$ & 650 \\
S5B-09 & Fabricate DPC/MPC/special purpose MPC and & & & \\
& overpack & 4 & $(3-6)$ & 36 \\
S5B-10 & Test DPC/MPC/special purpose MPC & 50 & $(26-78)$ & 100 \\
S5B-11 & CofC for DPC/MPC/special purpose MPC & 0 & & 0 \\
S5B-12 & SARP approval by regulatory agency & 0 & & 0 \\
S5B-13 & CofC approval by regulatory agency & $(123-410)$ & 1,038 \\
\hline Table S5B Sum of activities and costs [Duration = 124 weeks]: & & \\
\hline
\end{tabular}


4. Blank Inter-Site SNF Preparation Plan Tables 
Table \#. Description

\begin{tabular}{ccc}
$\begin{array}{c}\text { Duration } \\
\text { (wk) }\end{array}$ & $\begin{array}{c}\text { Sum of Activity } \\
\text { Times (wk) }\end{array}$ & $\begin{array}{c}\text { Cost } \\
(\$ K)\end{array}$ \\
\hline
\end{tabular}

Table J01. Joint shipper/receiver preparations.

Table S02. General preparation, shipper.

Table R02. General preparation, receiver.

Table S03. Plant/system activation, shipper.

Table R03. Plant/system activation, receiver.

Table S04. Transportation issues, shipper .

Table S06. ORR/RA preparations, shipper.

Table R06. ORR/RA preparation, receiver.

Table S07. CSEs \& SAR upgrades, shipper.

Table R07. CSEs and SAR upgrades, receiver.

Table S08. Environmental, shipper.

Table R08. Environmental, receiver.

Table S09. SNF preparation - canister fabrication \& loading, shipper.

Table S10. Canister to cask loading equipment design and fabrication, shipper.

Table R10. Canister from cask loading equipment design and fabrication, receiver.

Table S11. Cask handling equipment design and fabrication, shipper.

Table R11. Cask handling equipment design and fabrication, receiver.

Table S12. Procedure writing, shipper.

Table R12. Procedure writing, receiver.

Table S13. Operator training, shipper.

Table R13. Operator training, receiver.

Table S14. ORR/RA, shipper.

Table R14. ORR/RA, receiver.

Table S15. DOE ORR, facility fuel transfer, shipper.

Table R15. DOE ORR, facility fuel transfer, receiver.

Table S16. Joint efforts, shipper .

Table R16. Joint efforts, receiver.

\section{TOTAL}

Table S5A. Cask procurement by DOE for SNF shipments.

Table S5B. DPC/MPC or special purpose MPC procurement by DOE for SNF shipments.

(Wos)


Table \#

-Item \#

Description

Table J01. Joint shipper/receiver preparations.

J01-01 DOE notification for planning for specific SNF shipments

J01-02 Develop responsibility assignment matrix

J01-03 Receiver prepare, update, and issue fuel acceptance criteria (FAC) based on the intended storage facility

J01-04 Shipper characterizes SNF to be shipped and complete FAC for receiver approval

J01-05 Select cask \& backup cask and facilities*

J01-06 Prepare joint shipping/receiving plan

J01-07 Joint agreement on shipping/receiving plan

J01-08 Cask selected

J01-09 DOE/lease/or buy decision of cask

J01-10 Determine number of cask shipments

J01-11 Cask scheduling and availability

Table J01 Sum of activities and costs [Duration $=$ weeks]:

* The term cask could also includes the dual purpose cask (DPC), the multi-purpose canister (MPC) or the special purpose MPC. Tables S5A describes the activities for the procurement of a cask, Table S5B describes the activities for the procurement of a DPC or a MPC (standard or special). 
Table S02. General preparation, shipper.

S02-01 Revise schedule/budget plan request

S02-02 Change control board (CCB) approved - SNF transfers offsite

S02-03 Update project plan

S02-04 Project management

Table S02 Sum of activities and costs [Duration $=$ weeks]:

Table R02. General preparation, receiver.

R02-01 Revise schedule/budget plan request

R02-02 CCB approved - SNF transfers offsite

R02-03 Update project plan

R02-04 Project management

R02-05 Prepare inspection plan for fuel storage

Table R02 Sum of activities and costs [Duration $=$ weeks]:

Table S03. Plant/system activation, shipper.

S03-01 Start staffing increase

S03-02 Increase staff and train for SNF transfers offsite

S03-03 Facility/equipment mods/upgrades/refurbish \& tests

Table S03 Sum of activities and costs [Duration $=$ weeks]:

Table R03. Plant/system activation, receiver.

\begin{tabular}{ll|l}
\hline R03-01 Start staffing increase & & \\
R03-02 Increase staff \& train for SNF transfers from offsite & & \\
R03-03 Facility/equipment mods/upgrades/refurbish and tests & & \\
\hline Table R03 Sum of activities and costs [Duration $=$ weeks]: & \\
\hline
\end{tabular}


Table S04. Transportation issues, shipper.

S04-01 Lease cask and commit funds

S04-02 Cask safety analysis report for packaging (SARP) amendment

S04-03 Cask certificate of compliance (CofC) amendment

S04-04 Transportation plan and related issues

S04-05 Crane and rail load test \& PM's

S04-06 Cask shipment route determination \& approval

S04-07 Fuel shipment permits

S04-08 Shipment notifications

S04-09 Fuel shipment approvals by DOE

S04-10 Initiate fuel shipment(s)

S04-11 Selected cask available for use (window of availability)

Table S04 Sum of activities and costs [Duration $=$ weeks]:

Table S06. ORR/RA preparations, shipper.

S06-01 Department self assessment for readiness assessment

S06-02 Prepare plan-of-action (POA)

S06-03 Appoint readiness assessment (RA) team

S06-04 DOE review POA

S06-05 Train RA team

S06-06 Prepare implementation plan (IP)

S06-07 DOE review IP

S06-08 Department certification of readiness

S06-09 RA resolution of comments

Table S06 sum of activities and costs [Duration $=$ weeks]: 
Table R06. ORR/RA preparation, receiver.

\begin{tabular}{lll|l}
\hline R06-01 Department self assessment for RA & & \\
R06-02 & Prepare plan-of-action & & \\
R06-03 & Appoint RA team & & \\
R06-04 & DOE review POA & & \\
R06-05 & Train RA team & & \\
R06-06 & Prepare implementation plan & & \\
R06-07 & DOE review IP & & \\
R06-08 Department certification of readiness & & \\
R06-09 & RA resolution of comments & & \\
\hline Table R06 Sum of activities and costs: [Duration $=$ weeks]: & \\
\hline
\end{tabular}

Table S07. CSEs \& SAR upgrades, shipper.

S07-01 Prepare primary criticality safety evaluation (CSE)

S07-02 Update facility fuel list

S07-03 Prepare independent CSE

S07-04 Review CSEs/technical specification (TS) update

S07-05 Resolve CSEs/TS comments/technical review

S07-06 Radiation and environmental safety committee (RESC) review

S07-07 Resolve RESC comments

S07-08 Environmental safety and health (ES\&H) review

S07-09 Resolve ES\&H comments

S07-10 DOE review and comments for approval

S07-11 Resolve DOE comments for DOE approval

S07-12 Independent procedure validation

Table S07 Sum of activities and costs [Duration $=$ weeks]: 
Table R07. CSEs and SAR upgrades, receiver.

R07-01 Prepare primary criticality safety evaluation

R07-02 Update facility fuel list

R07-03 Prepare independent CSE

R07-04 Review CSEs/technical specification update

R07-05 Resolve CSEs/TS comments/technical review

R07-06 Radiation and environmental safety committee review

R07-07 Resolve RESC comments

R07-08 Environmental safety and health review

R07-09 Resolve environmental safety and health comments

R07-10 DOE review and comments for approval

R07-11 Resolve DOE comments for DOE approval

R07-12 Independent procedure validation

Table R07 Sum of activities and costs [Duration $=$ weeks]:

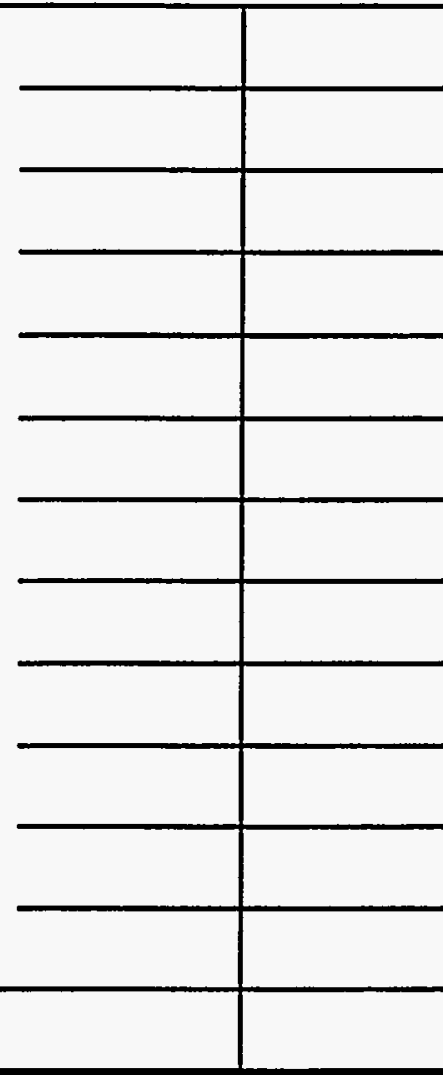

Table S08. Environmental, shipper.

S08-01 Review NEPA compliance issues

Table S08 Sum of activities and costs [Duration $=$ weeks]:

Table R08. Environmental, receiver.

R08-01 Review NEPA compliance issues

Table R08 Sum of activities and costs [Duration $=$ weeks]: 
Table S09. SNF preparation - canister fabrication \& loading, shipper.

S09-01 SNF fuel handling and shipping characterization data

S09-02 Determine equipment requirements

S09-03 Identify/design equipment

S09-04 Procure material

S09-05 Planning for equipment fabrication

S09-06 Equipment fabrication

S09-07 Equipment checkout

S09-08 Closeout for equipment fabrication

S09-09 As-bilt for fabricated equipment

Table S09 Sum of activities and costs [Duration $=$ weeks]:

Table S10. Canister to cask loading equipment design and fabrication, shipper.

S10-01 Identify/design equipment

S10-02 Procure material

S10-03 Planning for equipment fabrication

S10-04 Equipment fabrication

S10-05 Equipment checkout

S10-06 Closeout for equipment fabrication

S10-07 As-bilt for fabricated equipment

Table S10 Sum of activities and costs $[$ Duration $=$ weeks $]$ :

* Mat-Raw material, specialized equipment, etc., cost in addition to labor cost. 
Table R10. Canister from cask loading equipment design and fabrication, receiver.

\begin{tabular}{lll|l}
\hline R10-01 Identify/design equipment & & \\
R10-02 Procure material & & Mat \\
R10-03 Planning for equipment fabrication & & \\
R10-04 Equipment fabrication & & \\
R10-05 Equipment checkout & & \\
R10-06 Closeout for equipment fabrication & & \\
R10-07 As-bilt for fabricated equipment & & \\
\hline Table R10 Sum of activities and costs [Duration $=$ weeks]: &
\end{tabular}

Table S11. Cask handling equipment design and fabrication, shipper.

S11-01 Identify/design equipment - cask handling/transport loading

S11-02 Procure material

S11-03 Planning for equipment fabrication

S11-04 Equipment fabrication

S11-05 Equipment checkout

S11-06 Closeout for equipment fabrication

S11-07 As-bilt for fabricated equipment

Table S11 Sum of activities and costs [Duration $=$ weeks]: 
Table 11. Cask handling equipment design and fabrication, receiver.

R11-01 Identify/design equipment - cask handling/transport loading

R11-02 Procure material

R11-03 Planning for equipment fabrication

R11-04 Equipment fabrication

R11-05 Equipment checkout

R11-06 Closeout for equipment fabrication

R11-07 As-bilt for fabricated equipment

Table R11 Sum of activities and costs [Duration $=$ weeks]:

Table S12. Procedure writing, shipper.

S12-01 Develop and update procedures

S12-02 Validate procedures

S12-03 Procedure reviews \& resolution of comments

Table S12 Sum of activities and costs [Duration $=$ weeks]:

Table R12. Procedure writing, receiver.

R12-01 Develop and update procedures

R12-02 Validate procedures

R12-03 Procedure reviews \& resolution of comments

Table R12 Sum of activities and costs [Duration $=$ weeks]:

Table S13. Operator training, shipper.

S13-01 Preparations for training

S13-02 Training (20 hours for 2 Crews)

Table S13 Sum of activities and costs $[$ Duration $=$ weeks $]$ :

Table R13. Operator training, receiver.

R13-01 Preparations for training

R13-02 Training (20 hours for 2 Crews)

Table R13 Sum of activities and costs [Duration $=$ weeks]: 
Table S14. ORR/RA, shipper.

S14-01 Dry run for fuel handling

S14-02 Readiness assessment

S14-03 Prepare final report

S14-04 Closure of prestart findings

S14-05 Approval to start operation

S14-06 Ready for receipt/shipment of fuel

Table S14 Sum of activities and costs [Duration $=$ weeks]:

Table R14. ORR/RA, receiver.

R14-01 Dry run for fuel handling

R14-02 Readiness assessment

R14-03 Prepare final report

R14-04 Closure of prestart findings

R14-05 Approval to start operation

R14-06 Ready for receipt/shipment of fuel

Table R14 Sum of activities and costs [Duration $=$ weeks]:

Table S15. DOE ORR, facility fuel transfer, shipper.

S15-01 Emergency preparedness preparation

S15-02 Emergency preparedness drill

S15-03 DOE ORR

S15-04 DOE final report preparation

S15-05 Closure of prestart findings

S15-06 Approval to operate

Table S15 Sum of activities and costs [Duration $=$ weeks $]$ : 
Table R15. DOE ORR, facility fuel transfer, receiver.

R15-01 Emergency preparedness preparation

R15-02 Emergency preparedness drill

R15-03 DOE ORR

R15-04 DOE final report preparation

R15-05 Closure of prestart findings

R15-06 Approval to operate

Table R15 Sum of activities and costs [Duration $=$ weeks]:

Table S16. Joint efforts, shipper.

S16-01 Shipper/receiver schedule agreement

S16-02 Inspect and PM cask

S16-03 Prepare fuel, load cask, and ship

Table S16 Sum of activities and costs [Duration $=$ weeks]:

Table R16. Joint efforts, receiver.

R16-01 Receive cask, off-load fuel, and store/process

R16-02 Decontaminate and return empty cask

Table R16 Sum of activities and costs [Table RI6 Duration = weeks]:

TOTAL Sum of activities and costs [Total Duration $=$ weeks]: 
Table S5A. Cask procurement by DOE for SNF shipments.

\begin{tabular}{|c|c|c|c|}
\hline $\begin{array}{l}\text { Table \# } \\
\text { - Item \# }\end{array}$ & Description & $\begin{array}{l}\text { Time } \\
\text { (wk) }\end{array}$ & $\begin{array}{l}\text { Cost } \\
(\$ K) \\
\end{array}$ \\
\hline S5A-01 & Prepare procurement package and request for proposal & & \\
\hline S5A-02 & Prepare scope of work & & \\
\hline S5A-03 & Prepare specifications & & \\
\hline S5A-04 & Prepare design criteria & & \\
\hline S5A-05 & Develop planning schedule & & \\
\hline S5A-06 & Prepare/revise SARP for cask & & \\
\hline S5A-07 & Develop inspection plan & & \\
\hline S5A-08 & Bid and award & & \\
\hline S5A-09 & Fabricate cask & & \\
\hline S5A-10 & Test cask & & \\
\hline S5A-11 & CofC for cask & & \\
\hline S5A-12 & SARP approval by regulatory agency & & \\
\hline S5A-13 & CofC approval by regulatory agency & & \\
\hline Table S5. & Sum of activities and costs [Duration $=$ weeks]: & & \\
\hline
\end{tabular}


Table S5B. DPC/MPC or special purpose MPC procurement by DOE for SNF shipments.

\begin{tabular}{|c|c|c|c|}
\hline $\begin{array}{l}\text { Table \# } \\
\text { - Item \# }\end{array}$ & Description & $\begin{array}{l}\text { Time } \\
\text { (wk) }\end{array}$ & $\begin{array}{l}\text { Cost } \\
(\$ K)\end{array}$ \\
\hline S5B-01 & Prepare procurement package and request for proposal & & \\
\hline S5B-02 & Prepare scope of work & & \\
\hline S5B-03 & Prepare specifications & & \\
\hline S5B-04 & Prepare design criteria & & \\
\hline S5B-05 & Develop planning schedule & & \\
\hline S5B-06 & $\begin{array}{l}\text { Prepare/revise SARP for DPC/MPC/special purpose } \\
\text { MPC }\end{array}$ & & \\
\hline S5B-07 & Develop inspection plan & & \\
\hline S5B-08 & Bid and award & & \\
\hline S5B-09 & Fabricate DPC/MPC/special purpose MPC and overpack & & \\
\hline S5B-10 & Test DPC/MPC/special purpose MPC & & \\
\hline S5B-11 & CofC for DPC/MPC/special purpose MPC & & \\
\hline S5B-12 & SARP approval by regulatory agency & & \\
\hline S5B-13 & CofC approval by regulatory agency & & \\
\hline Table S5] & 3 Sum of activities and costs [Duration $=$ weeks]: & & \\
\hline
\end{tabular}




\section{Generic Inter-Site SNF Shipment Preparation Plan Schedules}

Using data from the generic cost tables, the following generic inter-site SNF preparation plan schedules were developed. These schedules clearly show the interrelationships between the various activities that are required for inter-site shipments of SNF. They are setup such that they can be initiated at any point in a year and the tie points are based on the "as late as" method. 


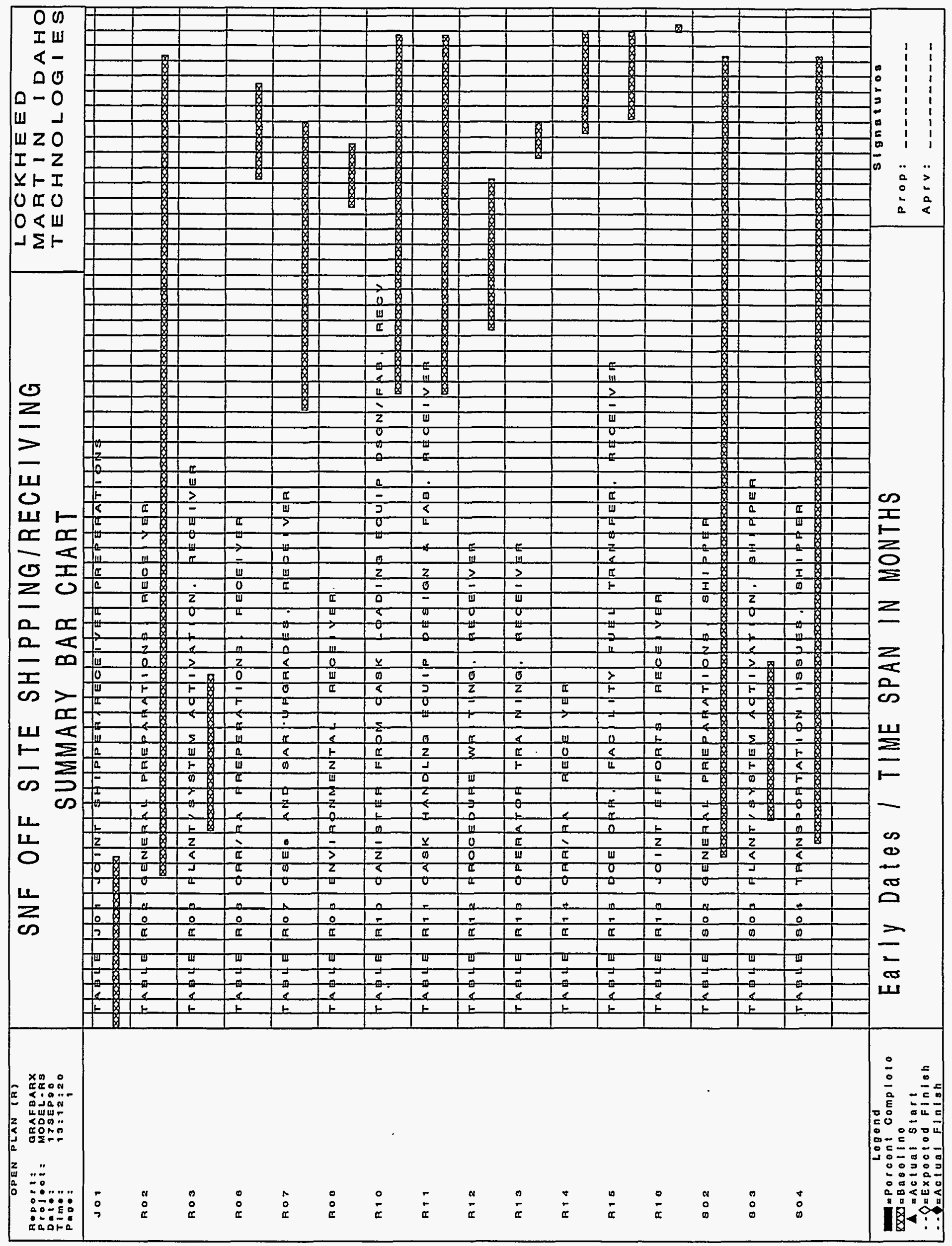




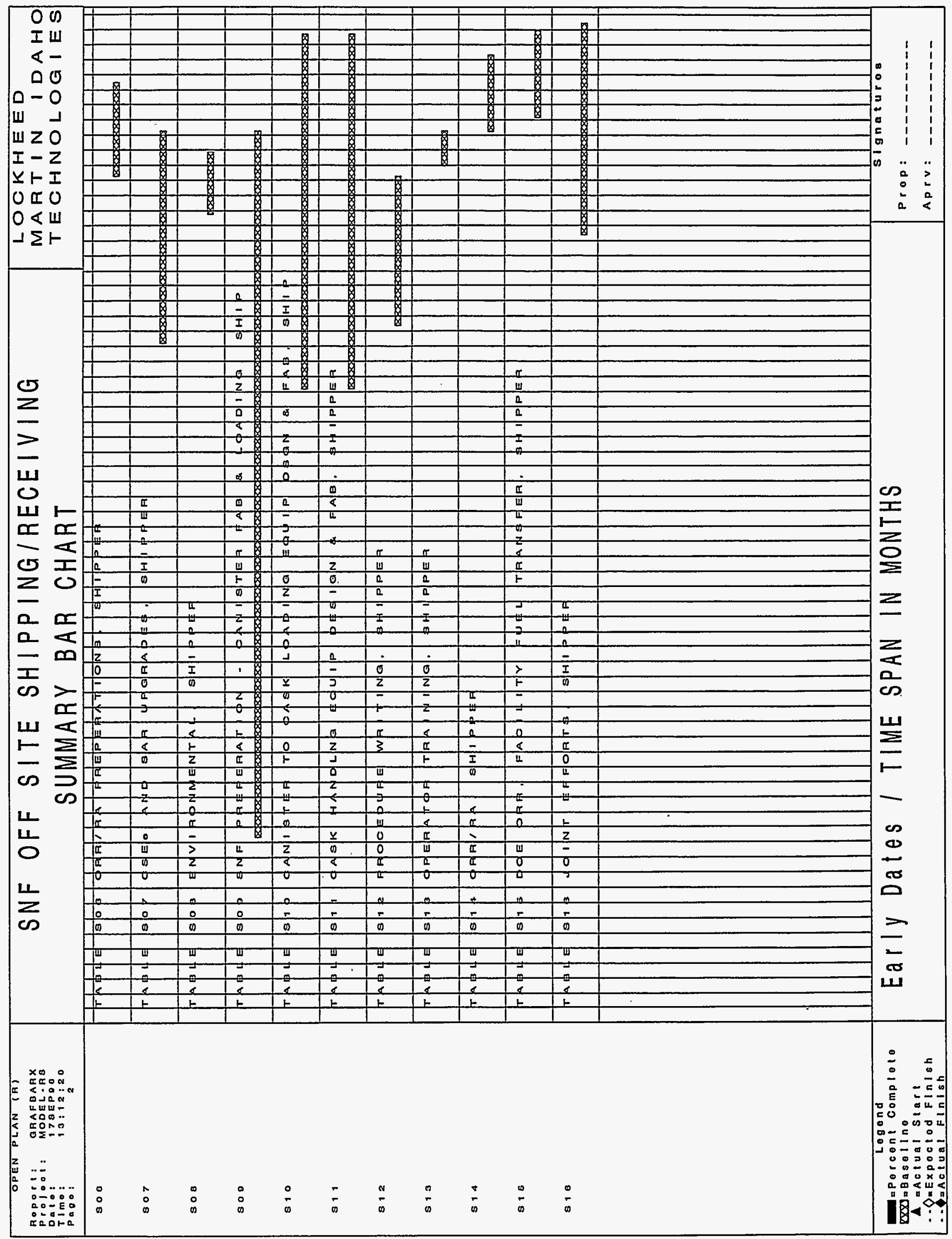


UOINT SHIPPING AND RECEIVING TABLE

TABLE JOS JOINT SHIPPEA/RECEIVEA PREPEAATIONS

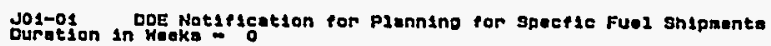

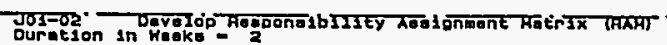

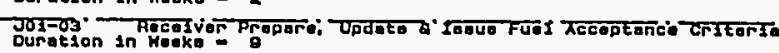

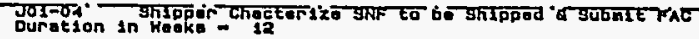

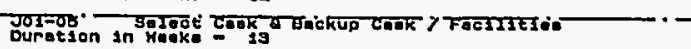

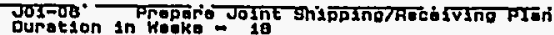

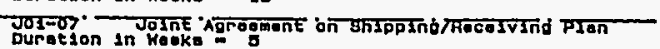

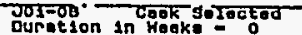

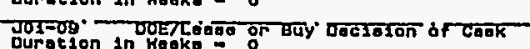

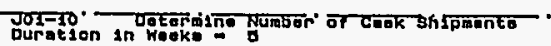

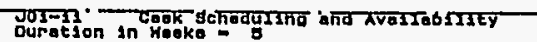

EECEIVEA'S TABLES

TABLE RO2 GENERAL PAEPARATIONS, RECEIVER

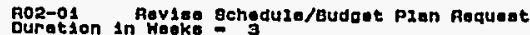

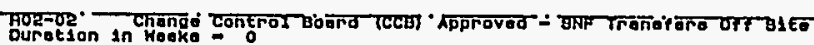

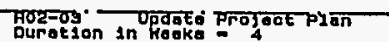

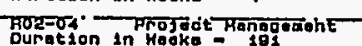

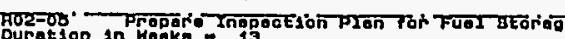

(1)

TABLE ROJ PLANT/SYSTEM ACTIVATION RECEIVEA

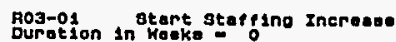

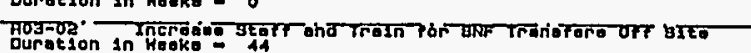

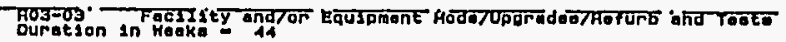

TABLE ROG ORA/AA PREPERATIONS. RECEIVEA

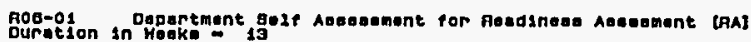

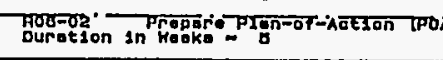

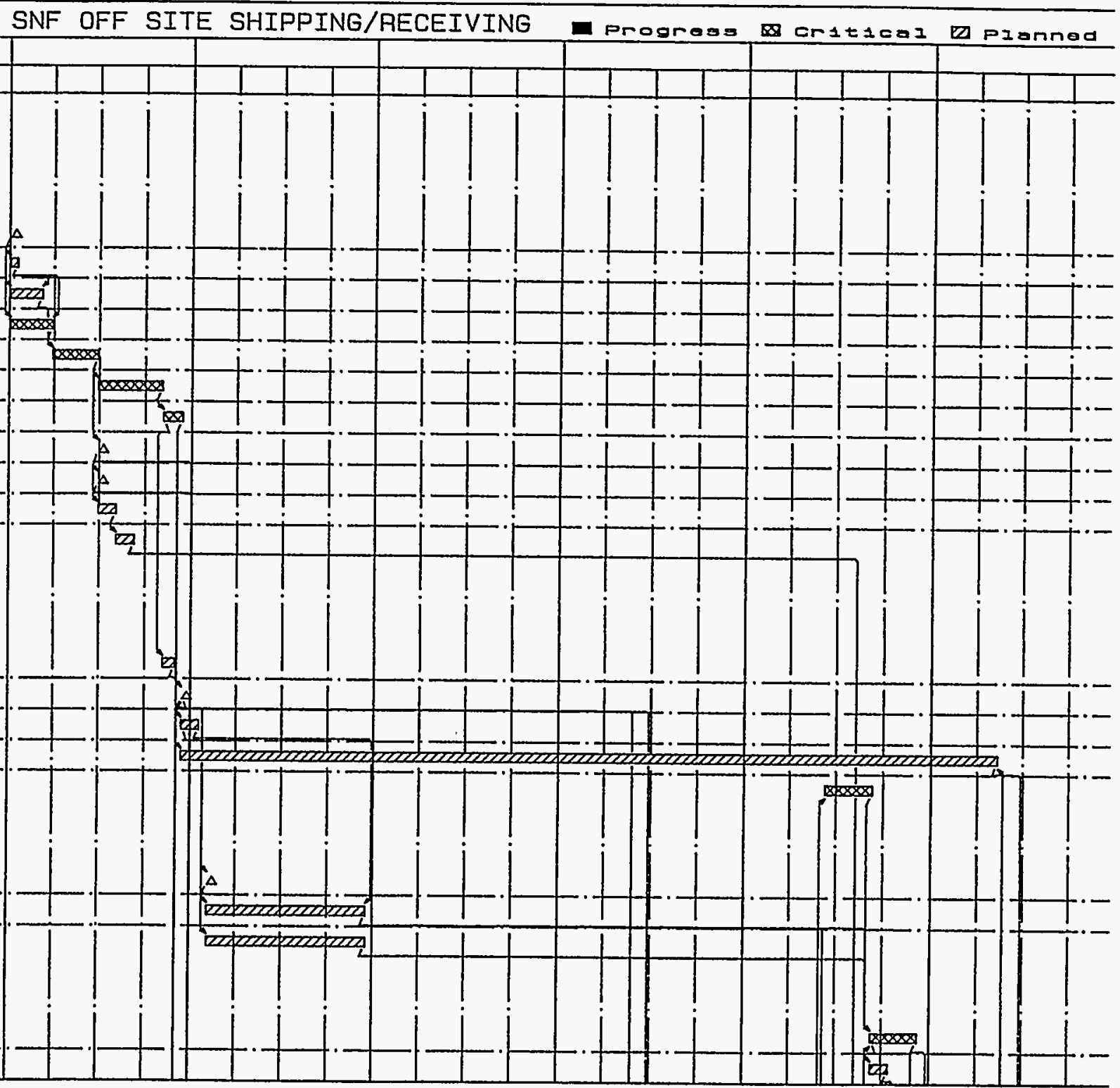




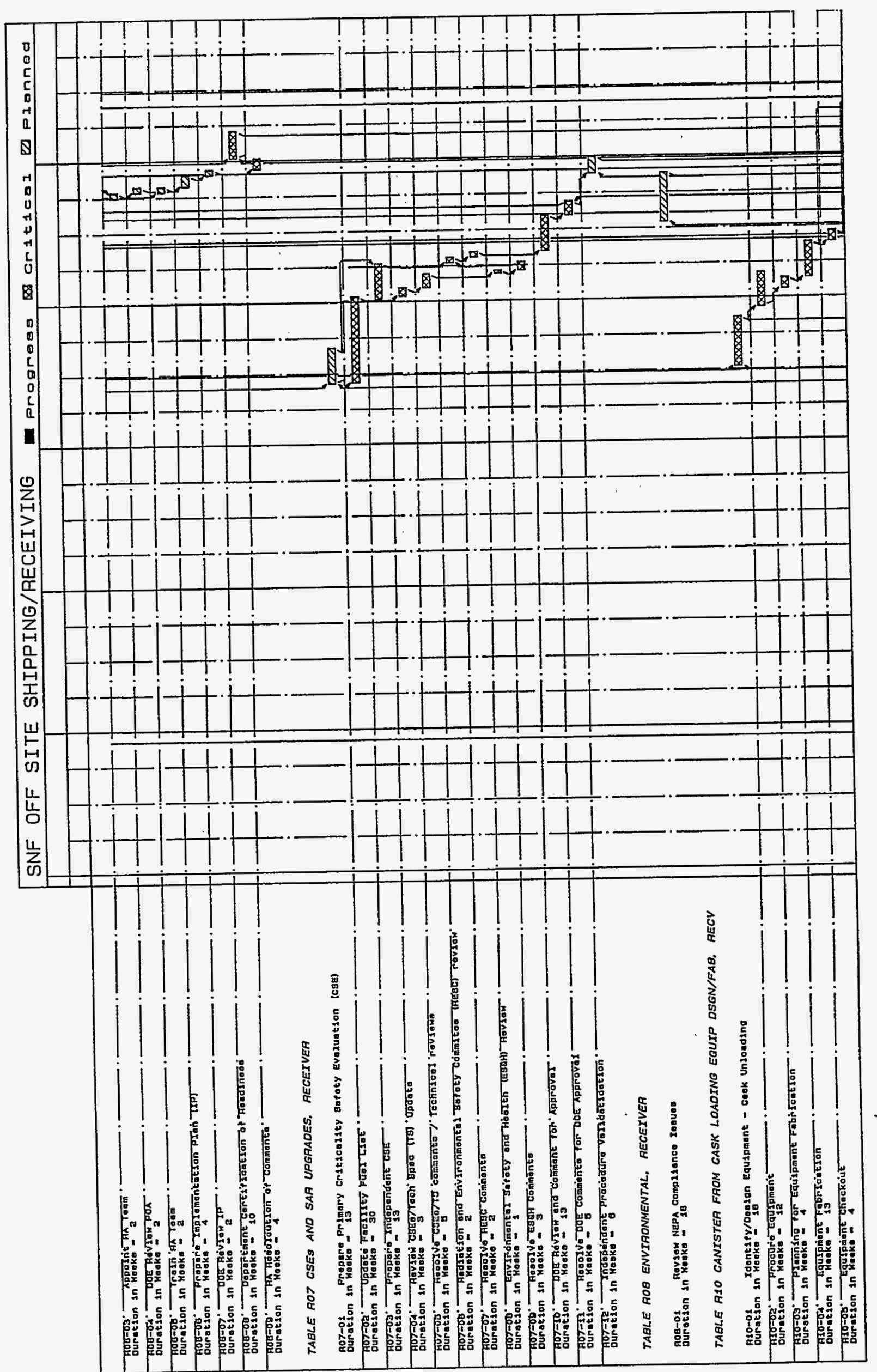




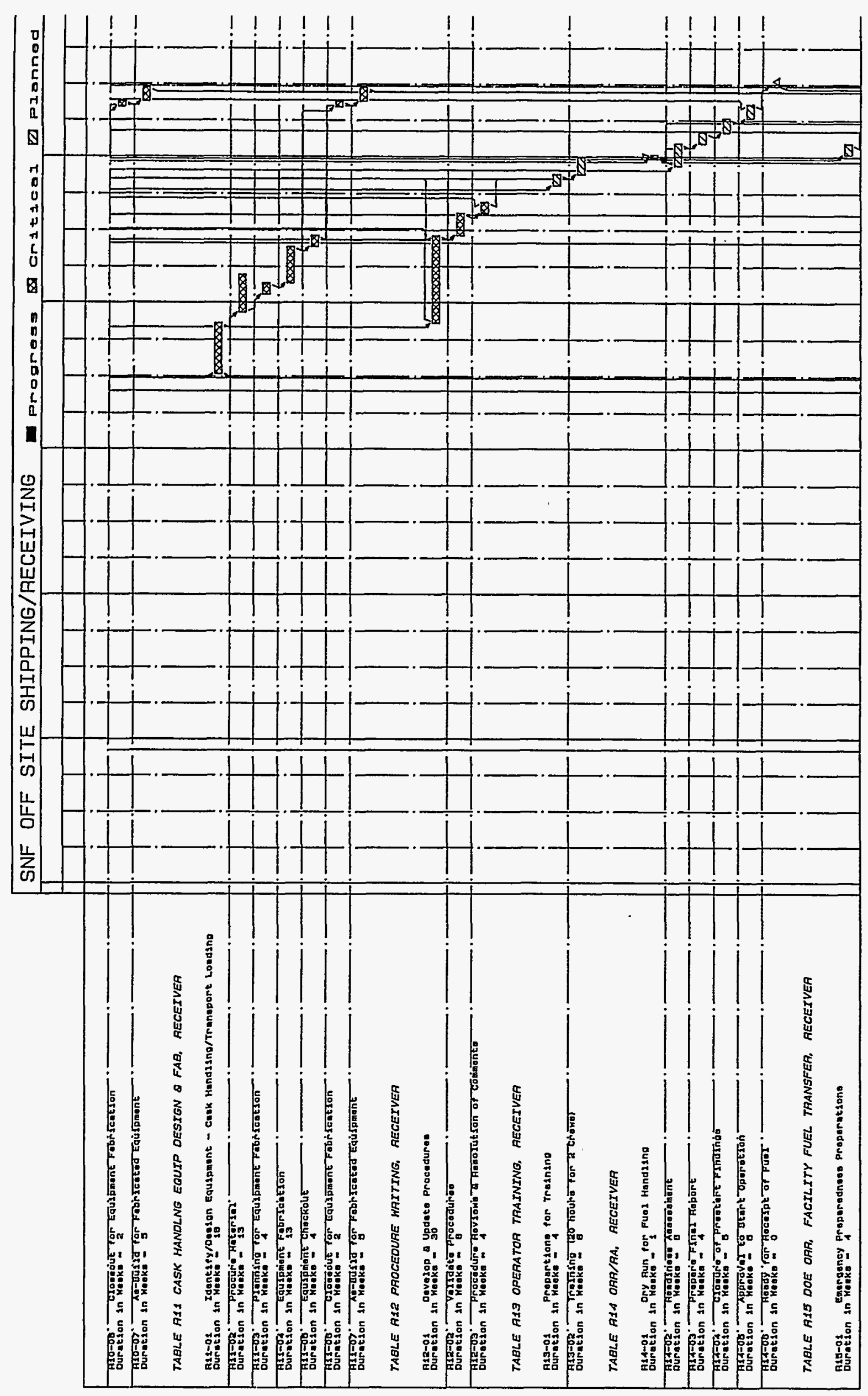




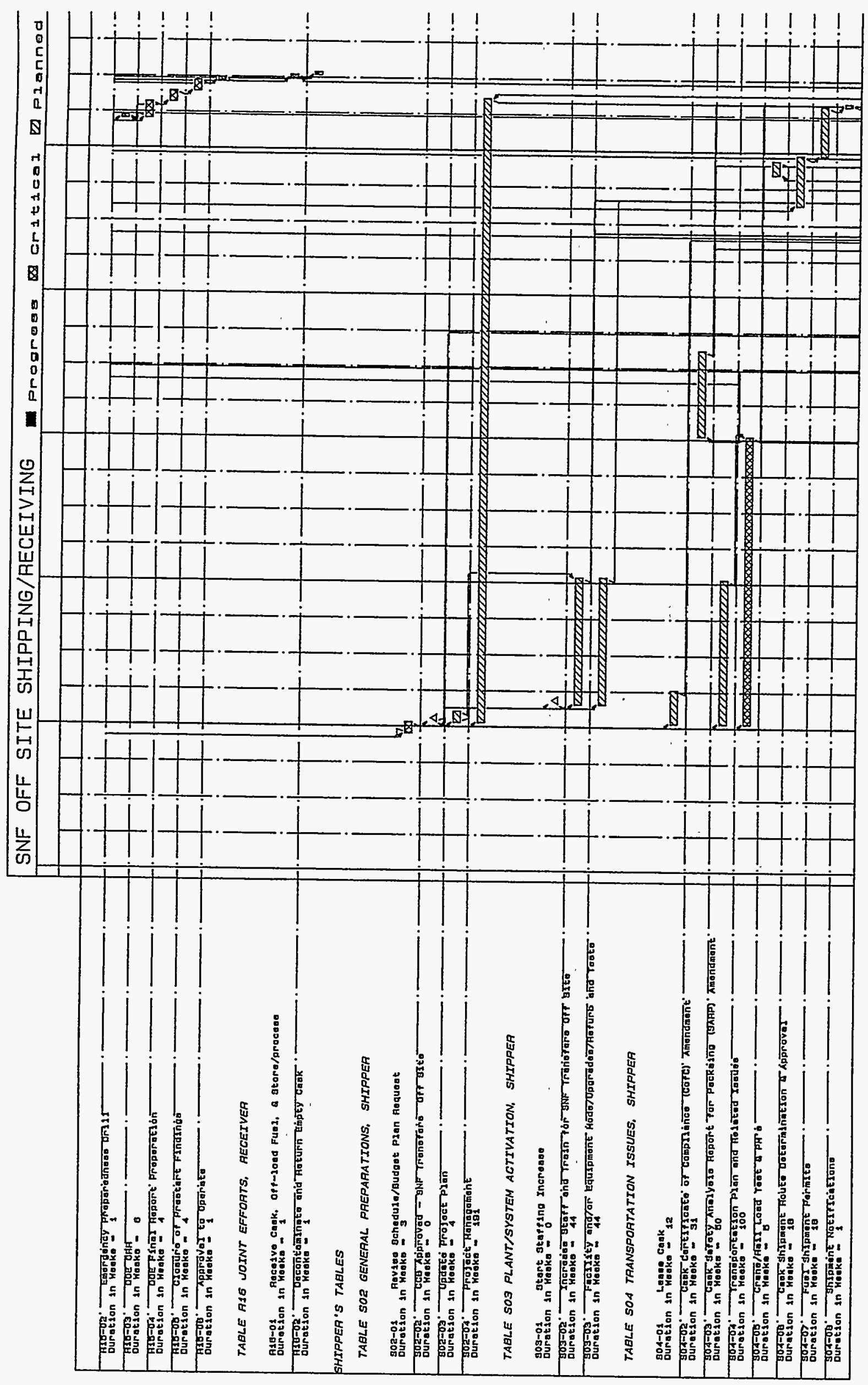




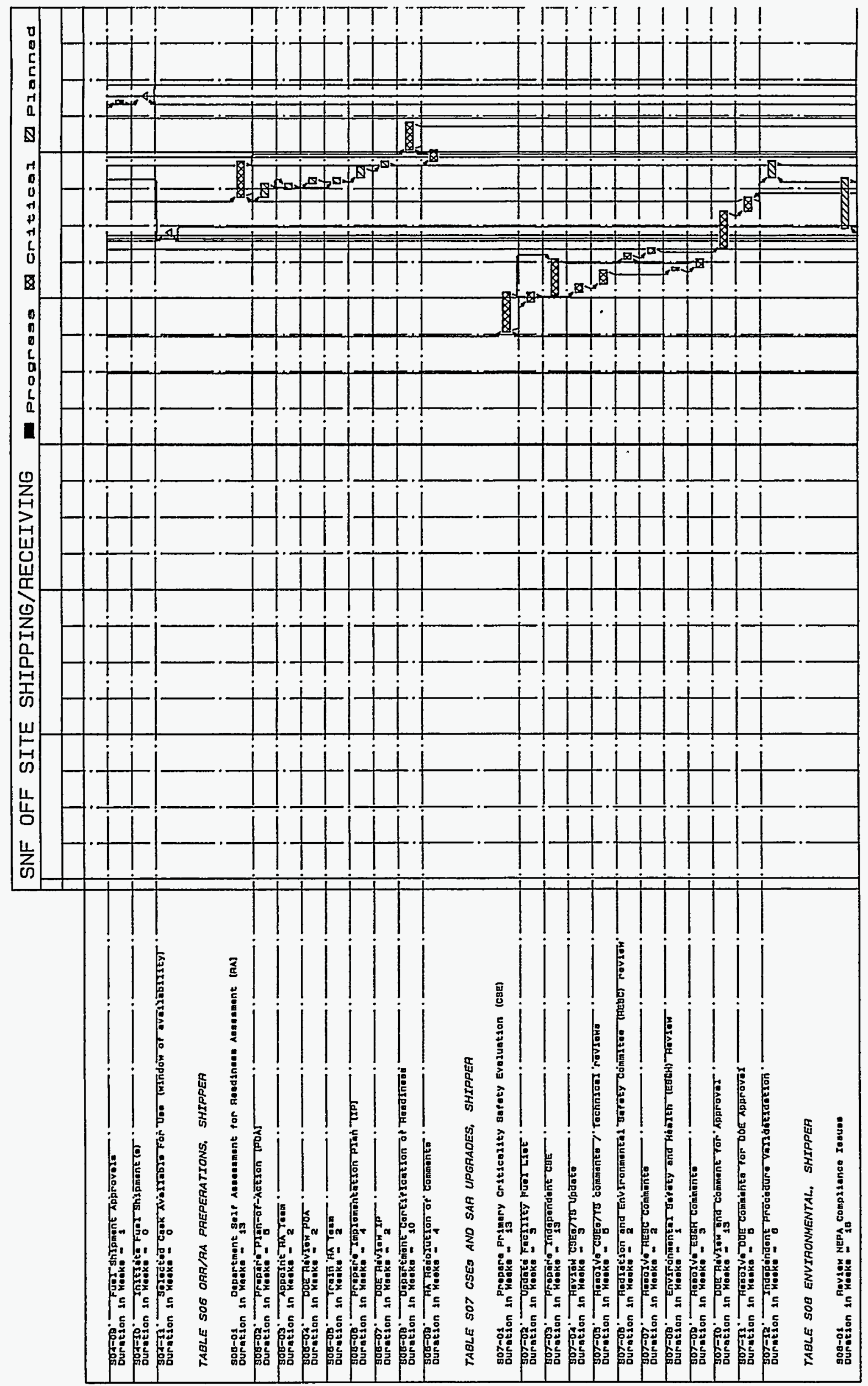




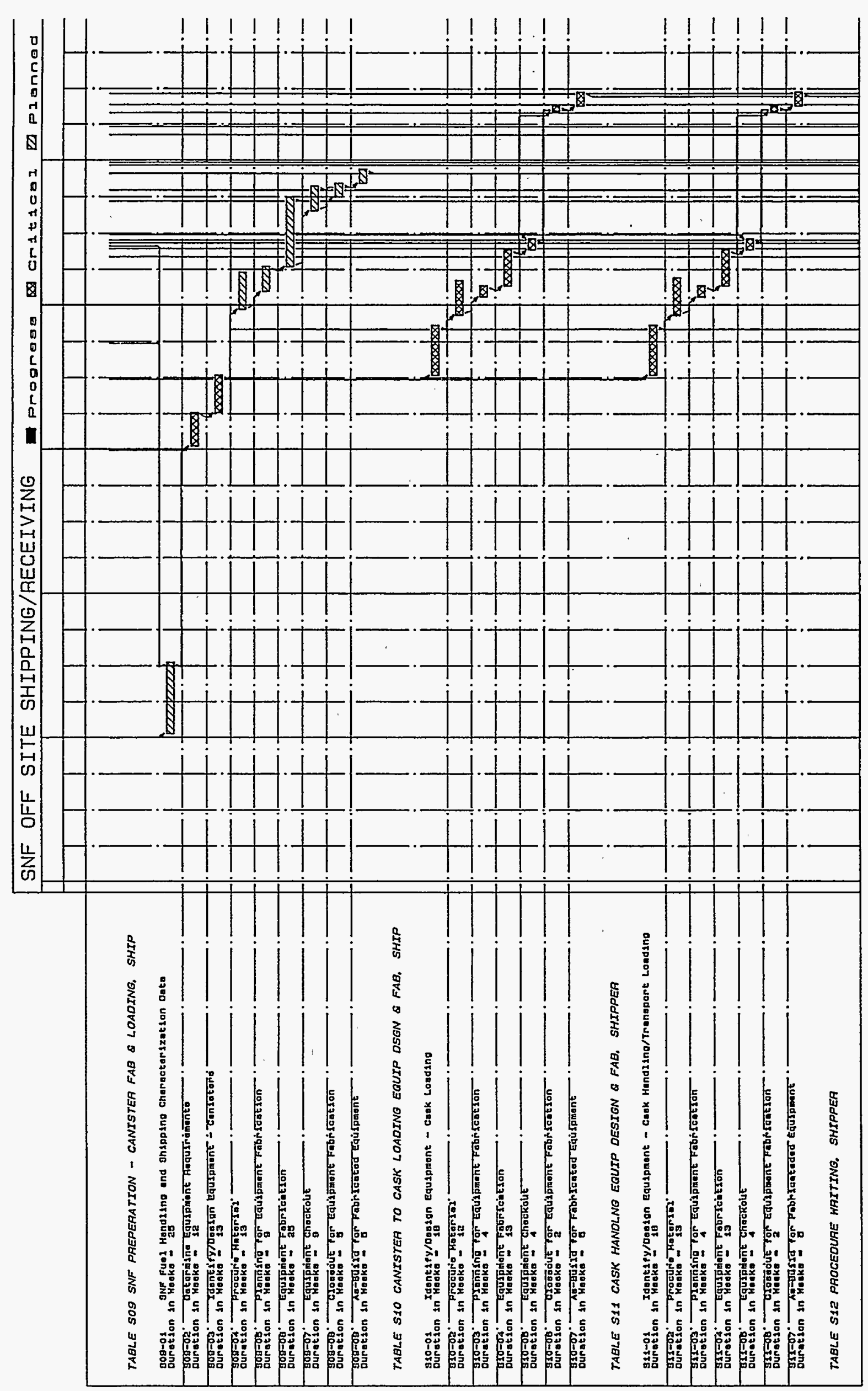




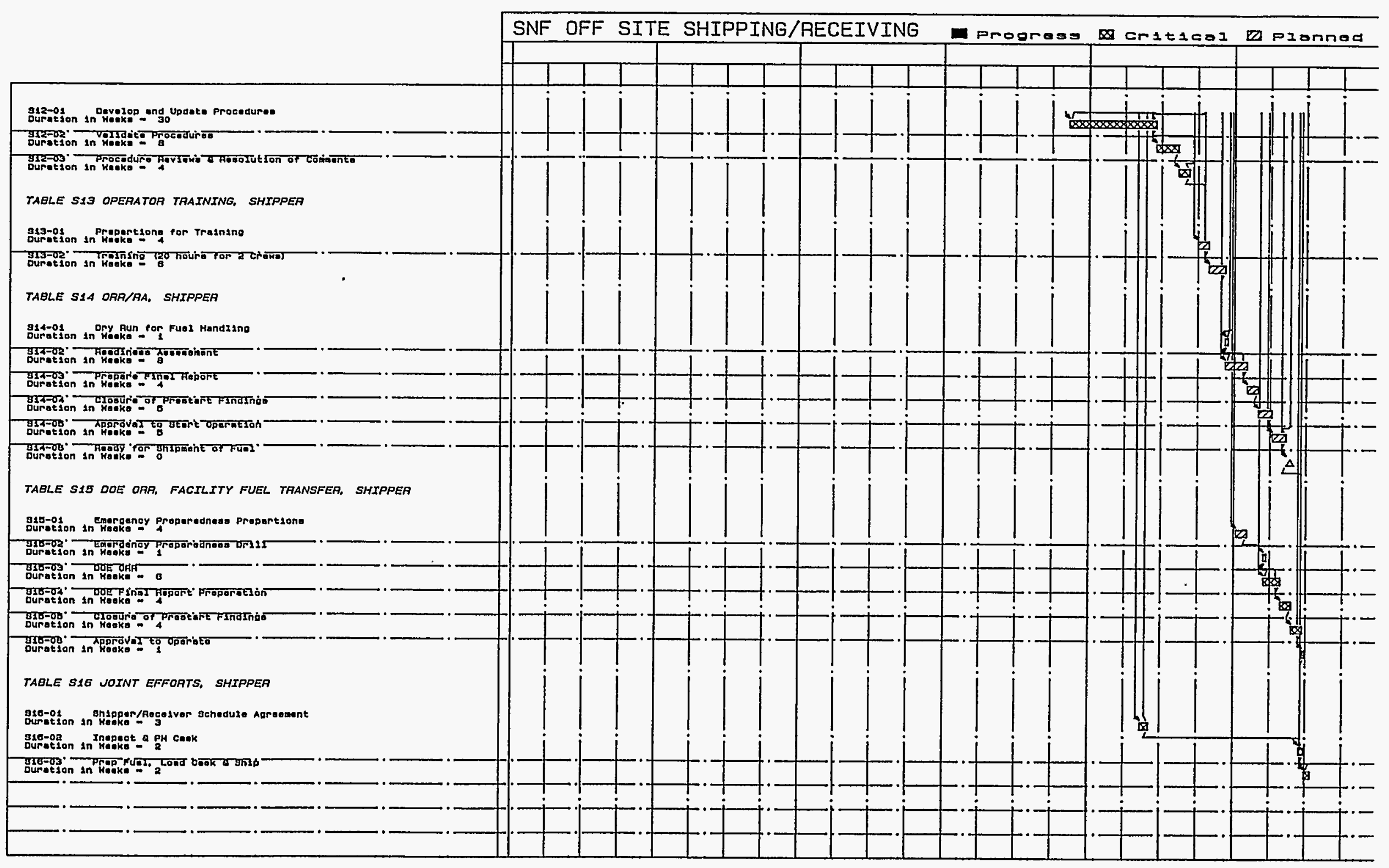




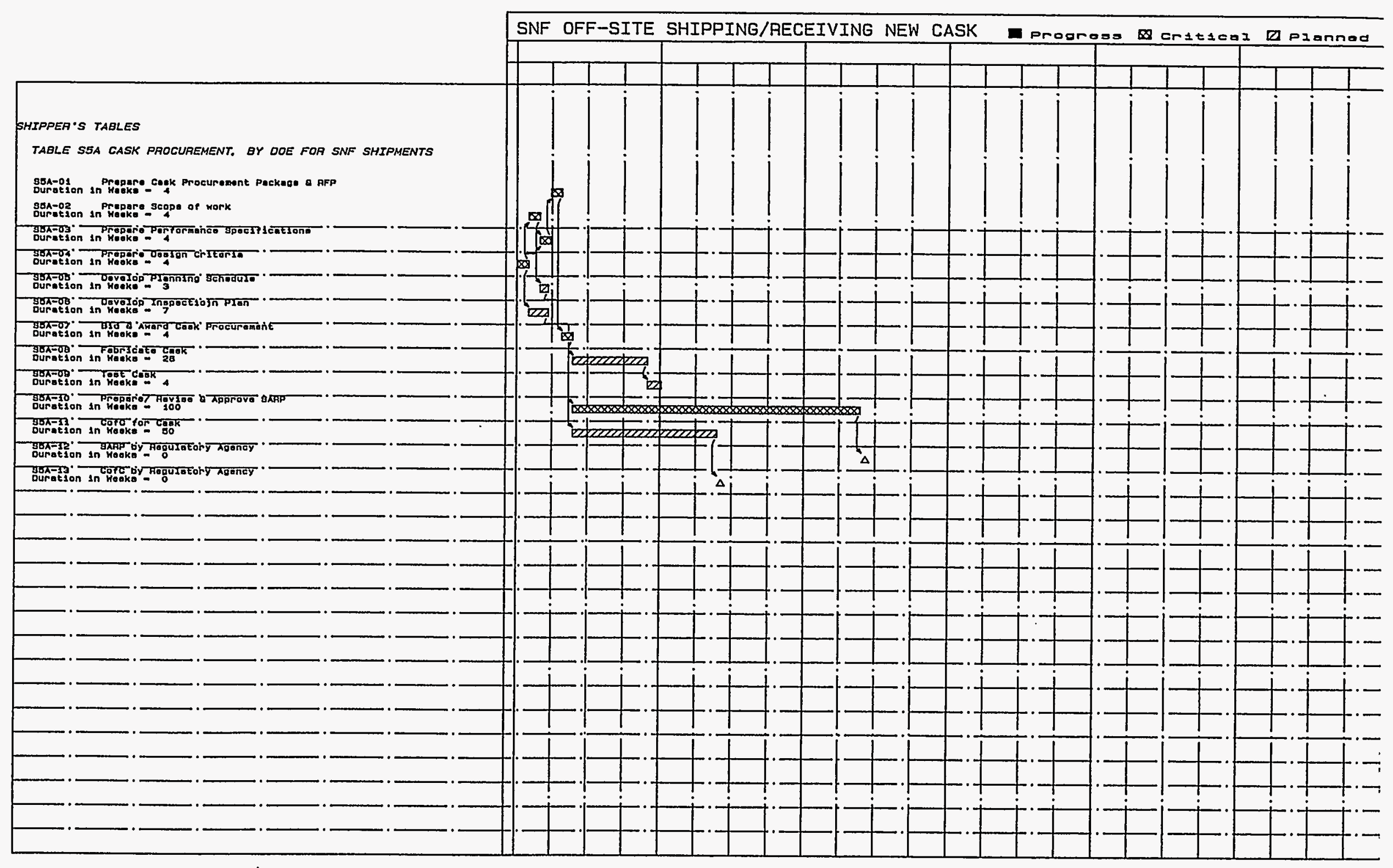




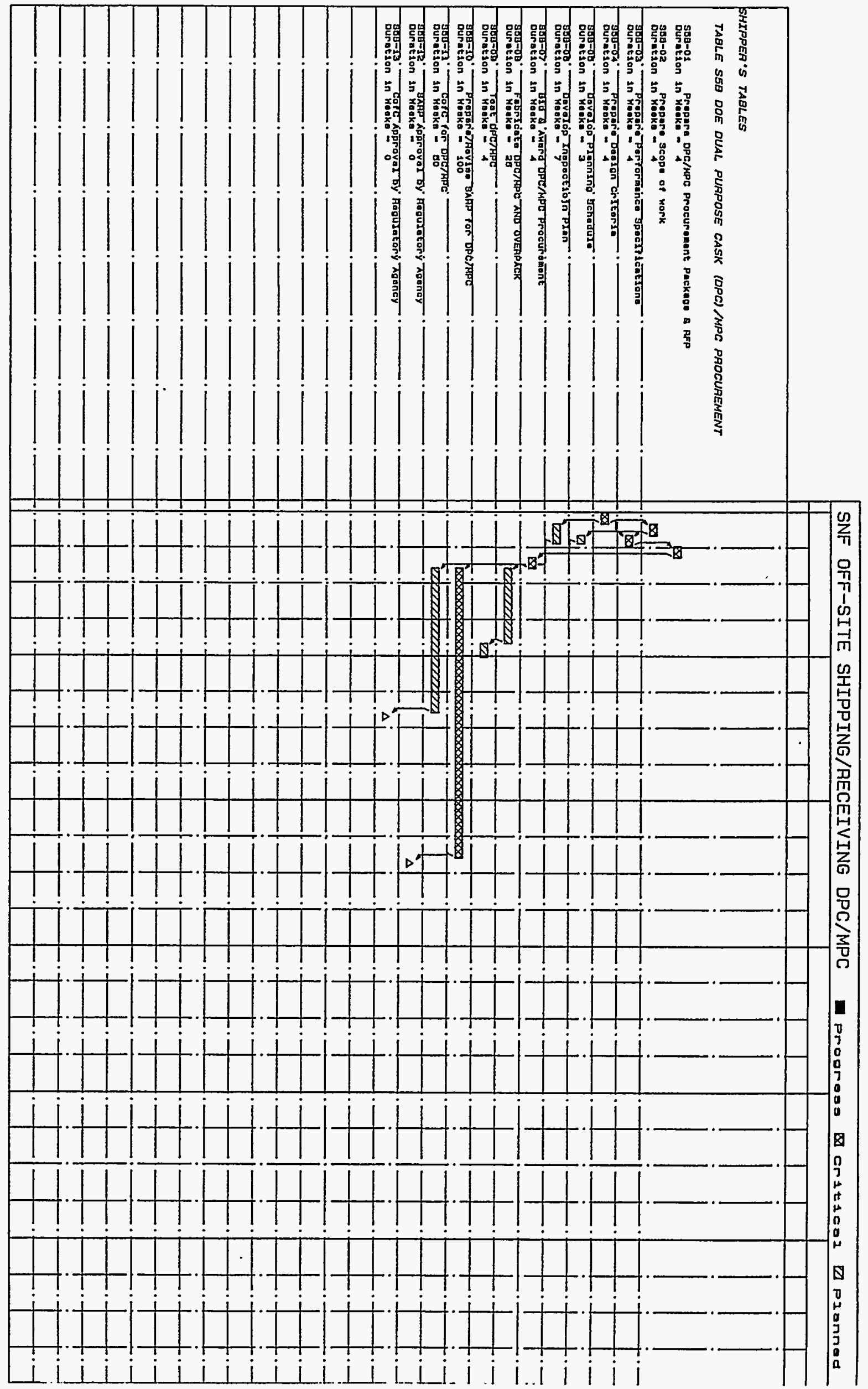




\section{Summary}

The Preparation Plan can provide a useful tool in setting up and estimate the costs and schedule of inter-site SNF shipments. The Generic Tables and Schedules provide both a typical case with the common ranges for the time required for each of the activities and a good starting point from which a specific shipping campaign can be based upon and estimated. 